\title{
Assessing risks and mitigating impacts of harmful algal blooms on mariculture and marine fisheries
} \author{
Elisa Berdalet ${ }^{4}$ and Charles R. Tyler ${ }^{1}$ \\ 1 College of Life and Environmental Sciences, University of Exeter, Exeter, UK \\ 2 College of Life and Environmental Sciences, University of Exeter, Penryn, UK \\ 3 Plymouth Marine Laboratory, Plymouth, UK \\ 4 Institute of Marine Sciences (ICM-CSIC), Barcelona, Spain
}

Andrew Ross Brown ${ }^{1}$ (D), Martin Lilley ${ }^{1}$, Jamie Shutler², Chris Lowe ${ }^{2}$, Yuri Artioli ${ }^{3}$, Ricardo Torres ${ }^{3}$,

\section{Correspondence}

Andrew Ross Brown, College of Life and Environmental Sciences, University of Exeter, Geoffrey Pope Building, Stocker Road, Exeter, Devon, EX4 4QD, UK. Email:

ross.brown@exeter.ac.uk

Received 27 August 2019; accepted 18 November 2019

\begin{abstract}
Aquaculture is the fastest growing food sector globally and protein provisioning from aquaculture now exceeds that from wild capture fisheries. There is clear potential for the further expansion of marine aquaculture (mariculture), but there are associated risks. Some naturally occurring algae can proliferate under certain environmental conditions, causing deoxygenation of seawater, or releasing toxic compounds (phycotoxins), which can harm wild and cultured finfish and shellfish, and also human consumers. The impacts of these so-called harmful algal blooms (HABs) amount to approximately 8 \$billion/yr globally, due to mass mortalities in finfish, harvesting bans preventing the sale of shellfish that have accumulated unsafe levels of HAB phycotoxins and unavoided human health costs. Here, we provide a critical review and analysis of HAB impacts on mariculture (and wild capture fisheries) and recommend research to identify ways to minimise their impacts to the industry. We examine causal factors for HAB development in inshore versus offshore locations and consider how mariculture itself, in its various forms, may exacerbate or mitigate HAB risk. From a management perspective, there is considerable scope for strategic siting of offshore mariculture and holistic Environmental Approaches for Aquaculture, such as offsetting nutrient outputs from finfish farming, via the co-location of extractive shellfish and macroalgae. Such pre-emptive, ecosystem-based approaches are preferable to reactive physical, chemical or microbiological control measures aiming to remove or neutralise HABs and their phycotxins. To facilitate mariculture expansion and long-term sustainability, it is also essential to evaluate HAB risk in conjunction with climate change.
\end{abstract}

Key words: food production, food quality, HABs, mariculture, phycotoxins, risk mitigation.

\section{Introduction}

Managing global food security is one of the greatest challenges of the twenty-first century. Currently, around 820 million people ( 1 in 9 people) suffer from malnutrition (FAO, IFAD, UNICEF, WFP and WHO, 2018) and this is projected to rise as the human population grows from 7.6 to a projected 11.2 billion by 2100 (UN, 2017). While agricultural productivity and yields from wild capture fisheries have plateaued or are in decline, aquaculture has grown substantially over the last forty years, particularly in Asia, a region which now supplies $\sim 90 \%$ of the global aquaculture market (FAO, 2018). Future food production in all sectors, however, may be limited by increasing climate variability, including extremes in rainfall intensity and temperature. These changes in climate in combination with increasing human population numbers, pollution events, impaired nutrient cycling, outbreaks of disease and pestilence are likely to result in future shortfalls in food production (FAO, 2018; FAO, IFAD, UNICEF, WFP and WHO, 2018). For aquaculture production, one of the most critical threats is the occurrence of harmful algal blooms (HABs). 
Increasing frequency of $\mathrm{HABs}$ is associated with climate change, nutrient enrichment and habitat disturbance and is leading to growing impacts, including the poisoning or asphyxiation of finfish, shellfish and poisoning of human consumers (Hallegraeff 1993; GESAMP, 2001; Smayda 2004; Anderson 2012; Berdalet et al. 2016). Harmful algal blooms can also cause a variety of other impacts affecting water quality, water flow and amenity value. Therefore, estimating the economic costs of HABs is complex and requires consideration of many different issues (see reviews by Berdalet et al. 2016; Adams et al. 2018). Among the biggest economic impacts of HABs are precautionary closures of fisheries and aquaculture farms to prevent human poisoning (see Section 'Global distribution and characterisation of HABs affecting human health through seafood consumption' on human poisoning). Annual costs of precautionary closures (US\$ at first point of sale) are estimated at $\$ 3-4$ billion: $>\$ 0.03$ billion in the UK (ASIMUTH, 2014); \$0.9-1.2 billion in the EU (Hoagland \& Scatasta 2006; S-3 EuroHAB, 2019); \$0.1-1.0 billion in Korea, Japan and China (Kim 2006; Trainer \& Yoshida 2014); and $>\$ 0.10$ billion in the USA (Hoagland et al. 2002). Furthermore, the worldwide economic impacts of marine phycotoxins on human health are estimated to be approximately $\$ 4$ billion a year (GESAMP, 2001; references in Berdalet et al. 2016). These estimates are very much 'best approximations' rather than detailed economic assessments (as conceded by some of the authors, e.g., Hoagland \& Scatasta 2006; Adams et al. 2018). According to conservative epidemiological assessments, around 2000 cases of HAB-related food poisonings occur each year globally, following human consumption of contaminated finfish or shellfish, and around $15 \%$ of these cases prove fatal (FAO, 2012; CTA, 2013). The proportion of farmed versus wild-caught finfish and shellfish that contain phycotoxins and subsequently poison human consumers is not currently known.

Food fish production from aquaculture (80 million tonnes, US $\$ 232$ billion per year) now exceeds capture fisheries (Table 1, adapted from FAO, 2018). Growth projections see this production from aquaculture rising by $37 \%$, from 70 million tonnes to 109 million tonnes, by 2030 (FAO, 2018), with a significant contribution coming from the global expansion of mariculture (Kapetsky et al. 2013). Food fish production from mariculture currently amounts to
28.7 million tonnes, of which more than half comes from bivalve shellfish. Bivalves are among the most sustainable mariculture products, since they derive their food entirely from naturally occurring food sources, predominantly marine planktonic microalgae. The growth of these algae is fuelled by natural (and anthropogenic) nutrient supplies from land runoff and coastal upwelling (Huston \& Wolverton 2009). Farming of aquatic plants and algae, dominated by seaweeds (macroalgae), has also increased recently to $>30$ million tonnes (FAO, 2018), worth an estimated US $\$ 11.7$ billion. The largest share of seaweed production is for human food products (polysaccharide carbohydrates and micronutrients), and the remainder is for animal feeds, fertilisers and biopolymers (Nayar \& Bott 2014).

Around 200 marine species are currently farmed, with the greatest variety in tropical seas (FAO, 2015; Froehlich et al. 2016). Species can be divided into two broad categories: (i) fed species, including finfish and some crustaceans and (ii) 'extractive' species, including (a) unfed filter-feeding bivalves, algal grazers, detritivores and (b) autotrophic plants, mainly macroalgae. Each of these categories has different environmental susceptibilities, interactions and installation planning issues (Gentry et al. 2016), particularly at inshore sites $(\leq 1 \mathrm{~km}$ from the coast). At inshore sites, mariculture is directly influenced by anthropogenic activities (agricultural and urban runoff, municipal and industrial effluent inputs, ships and mariculture itself), which potentially increase HAB risk (Anderson et al. 2008; Anderson 2012). Recent calculations have suggested that current seafood consumption could be met by extending mariculture offshore, into less than 1\% of Exclusive Economic Zones belonging to coastal states (Gentry et al. 2017). Some HABs, however, originate in open oceanic waters (Davidson et al. 2009, 2016; Trainer et al. 2012; Shutler et al. 2015; Gobler et al. 2017), indicating that some algal species may present similar or even greater risks as mariculture moves offshore.

Mariculture represents the nexus of environment-foodhealth systems, with food productivity and quality depending on clean coastal waters and healthy intact marine ecosystems (FAO, IFAD, UNICEF, WFP and WHO, 2018). To ensure long-term sustainable growth of the industry, a collection of interconnecting issues covering biosecurity, economic and environmental aspects (including climate

Table 1 Global food fish production from aquaculture in 2016

\begin{tabular}{lrcccc}
\hline Aquaculture production & Finfish & Molluscs & Crustacea & Other & Total for aquaculture \\
\hline By weight (million tonnes) & 54.1 & 17.1 & 7.9 & 1.0 & $80 *$ \\
By value (billion US\$) & 138.5 & 29.2 & 57.1 & 6.8 & 232 \\
\hline
\end{tabular}

*Mariculture currently provides 36\% (28.7 million tonnes) of food fish production from all forms of aquaculture (including freshwater and recirculating systems) and is dominated by molluscs (17.1 million tonnes; FAO, 2018). 
change and HABs) need to be addressed (De Silva \& Soto 2009; Lovatelli et al. 2013). Here, we critically review national and international $\mathrm{HAB}$ monitoring data records and published literature, to evaluate the occurrences, causes and impacts of HABs on shellfish and finfish mariculture in inshore and offshore waters. We identify environmental factors contributing to $\mathrm{HAB}$ risk and establish whether mariculture practices themselves can influence (increase or reduce) risks of $\mathrm{HAB}$ occurrence and impact. Methods for predicting and mitigating $\mathrm{HAB}$ risk are then reviewed. The risks of HABs to wild capture fisheries, as well as mariculture, are considered in this review also, since mariculture has the potential to attract and promote aggregations of wild finfish and shellfish. Building improved understanding of $\mathrm{HAB}$ risk for these related industries is of paramount importance to ensure future marine food security and safety.

\section{Impacts of HABs on marine fisheries and mariculture}

Nature of HABs and their impacts

Harmful algal blooms are proliferations of certain microalgae, macroalgae or blue/green algae (cyanobacteria), which under favourable environmental conditions reach certain levels that can have negative impacts on humans or the aquatic environment (Hallegraeff 1993; Anderson 2012; Bresnan et al.2013; GlobalHAB, 2017). Some HAB species or strains synthesise phycotoxins that are ingested by marine plankton grazers and potentially bioaccumulate in higher food chain organisms, including humans. Ephiphytic HAB species including Prorocentrum lima, Ostreopsis spp. and Gambierdiscus spp. have the potential to contaminate seaweeds, but human poisonings are generally caused by the consumption of seaweed grazing herbivorous shellfish, finfish or their predators, rather than from direct consumption of seaweeds. Globally, around $300 \mathrm{HAB}$ species have been identified, of which more than a third, mainly in the dinoflagellate group, are known to produce toxins that are harmful to aquatic organisms and/or to humans consuming them (http://www.marinespecies.org/hab/index. php; Anderson 2012). Toxin production can vary between different genetic strains for some HAB species (e.g. Touzet et al. 2010; Cochlan et al. 2012) and/or different environmental conditions (Fehling et al. 2004; Wells et al. 2005). Poisoning syndromes in humans, responsible HAB genera, phycotoxin groups, and shellfish, finfish and macro-algal vectors of these phycotoxins are summarised in Section 'Global distribution and characterisation of HABs affecting human health through seafood consumption' (Table 2). Other metabolites may also be generated from these toxins, many of which have not been characterised in terms of chemical structure, potency or public health significance (Wiese et al. 2010; Anderson 2012). Other $\mathrm{HAB}$ species cause harm to fish through gill clogging or via the production of fish toxins (ichthyotoxins). Also, when the blooms decay, the degradation of the accumulated algal biomass by bacteria results in oxygen depletion, affecting aquatic ecosystems as a whole (Smayda 2004; Svendsen et al. 2018).

Global distribution and characterisation of HABs affecting human health through seafood consumption

Information concerning the global occurrence and impact of $\mathrm{HAB}$ events is recorded in the Harmful Algae Event Database (HAEDAT, http://haedat.iode.org). Bivalve molluscs, which filter and feed directly on microalgae, including $\mathrm{HAB}$ species, are the principal vectors for shellfish poisoning in humans. Crustaceans that prey upon intoxicated bivalves, including crabs and lobsters (Shumway 1995; James et al. 2010), and also carnivorous finfish (Friedman et al. 2017) can also bioaccumulate and in turn act as important vectors for phycotoxins. Table 2 summarises the principal poisoning syndromes that result from humans ingesting intoxicated shellfish or finfish and the respective geographical areas of highest incidence.

The phycotoxins associated with each poisoning syndrome (column 1 of Table 2) are neurotoxins, and they are heat-stable (and thus unaffected by cooking), underlining their risk to human health. Global maps of reported shellfish poisonings are illustrated in Manfrin et al. (2012), and selected references on poisoning syndromes can be found in Berdalet et al. (2016). Microalgae can produce a broader spectrum of toxic compounds than illustrated in Table 2 and include yessotoxins (YTXs) and pectenotoxins (PTXs) that mainly cause diarrhoea (Reguera et al. 2014). An increasing number of toxic compounds derived from algae are being detected as monitoring and analytical tools become more advanced, including brevetoxins (Turner et al. 2015) and cyclic imines (Davidson et al. 2015).

\section{Occurrences and impacts of HABs on marine organisms in fisheries and mariculture}

Evidence on the occurrence and impacts of $\mathrm{HAB}$ on marine fisheries and mariculture is being gathered by ongoing regional programmes (e.g. Maguire et al. 2016), national programmes (e.g. UK FSA, https://www.food.gov.uk/busi ness-guidance/biotoxin-and-phytoplankton-monitoring) and global (GlobalHAB, 2017) programmes (see section 'In situ monitoring'). However, despite the increasing coordination and integration of $\mathrm{HAB}$ monitoring programmes and research, not all incidents are captured and records may not always tally between local and global databases (e.g. HAEDAT). Some HABs are difficult to detect, notably 


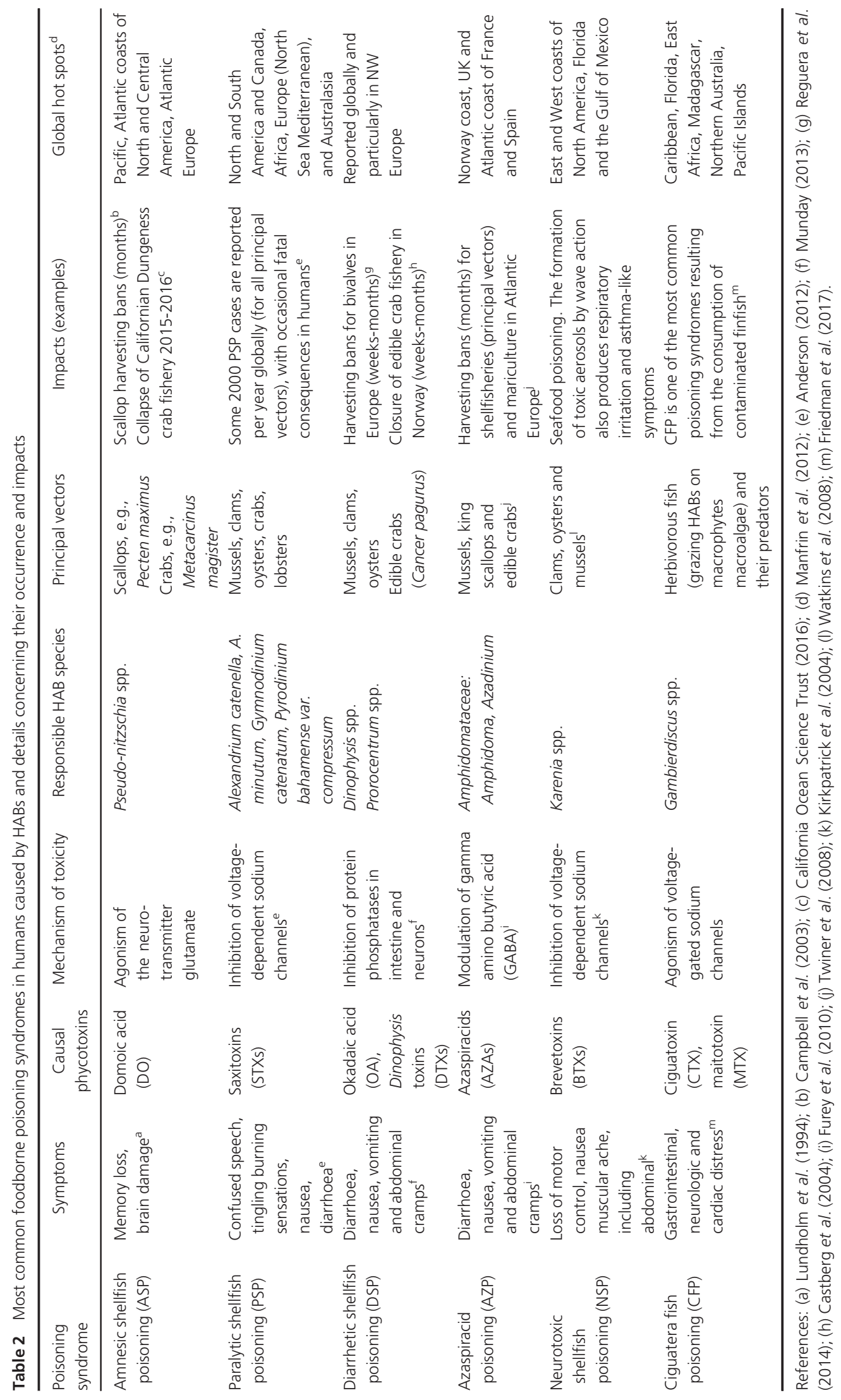


for species which bloom below the sea surface and evade in situ monitoring and satellite imaging (Shutler et al. 2015). It is also often difficult to attribute cause(s) to observed impacts on complex marine systems, particularly when they involve cryptic species and nonspecific mechanisms, such as the depletion of dissolved oxygen and suffocation of (shell)fish by HABs such as Karenia mikimotoi (Davidson et al. 2009; Shutler et al. 2015). Since the 1960s, the number of hypoxic or anoxic 'dead zones' in coastal waters has doubled every decade (Diaz \& Rosenberg 2008). This has occurred in conjunction with increasing eutrophication caused by nutrient enrichment and excessive algal growth. In some cases, notable asphyxiation impacts on finfish and shellfish have been attributed to high biomass blooming HAB species such as Phaeocystis spp., Karenia spp. and Aureococcus anophagefferens (Peperzak \& Poelman 2008; Davidson et al. 2009; Gobler et al. 2011).

Evidence of acute toxicity from HABs on finfish and shellfish in wild fisheries and mariculture

Harmful algal bloom species from different taxonomic groups with few commonalities (dinoflagellates, dictyophytes, haptophytes, prymnesiophytes, raphidophytes) have been implicated in major finfish kills in marine fisheries and mariculture. In some cases, the toxicity can be transmitted up the food chain to seabirds and marine mammals. Widely cultured finfish species affected by HABs include Atlantic salmon (Salmo salar), Rainbow trout (Onchorhynchus mykiss) and Yellowtail amberjack/kingfish (Seriola quinqueradiata) (reviewed by Landsberg 2002; Clément et al. 2016). Nevertheless, the mechanisms of toxicity for 'fish killing HABs' are not well understood. An example illustrating the complexity associated with HAB toxicity in finfish is presented for Heterosigma akashiwo. Here, effects may be due to the production of reactive oxygen species, brevetoxin-like compound(s), excessive mucus production that impedes oxygen exchange, gill tissue damage by mucocysts and/or haemolytic activity. Uncertainties arise when there are differences in the toxicity of wild $\mathrm{HAB}$ populations versus laboratory cultures; for example, reduced toxicity has been shown to result from the longterm culturing of H. akashiwo (Cochlan et al. 2012). There may also be variability in mucocyst production by different strains of microalgae (in the case of Pseudochattonella farcimen; Andersen et al. 2015).

Marine fisheries (and other wildlife). Some of the largest and most regular finfish (and other wildlife) kills occur annually along Florida's Gulf coast. Here, epidemiological assessments have attributed these to brevetoxin poisonings from blooms of the dinoflagellate Karenia brevis (Landsberg et al. 2009; Flaherty \& Landsberg 2011). A recent bloom of $K$. brevis lasted over a year, beginning in
November 2017, extending for a distance of 150-200 miles along Florida's Gulf coast and killed hundreds of tonnes of marine life, including thousands of small fish, numerous large fish (including groupers and a 21 - $\mathrm{ft}$ whale shark) and marine mammals, including dolphins (Pickett 2018). The 2017-2018 bloom is one of the longest and most severe outbreaks recorded over the last 70 years and illustrates the scale of impacts possible from a single $\mathrm{HAB}$ outbreak (Krimsky et al. 2018). Elsewhere, for example in the UK (1978, 1980) and Ireland (1976, 1978, 1979 and 2005), major finfish and shellfish kills have been attributed to Karenia mikimotoi (a.k.a. Gyrodinium (or Gymnodinium) aureolum; e.g. Silke et al. 2005; Mitchell \& Rodgers 2007). These blooms have caused widespread death of wild and cultured fish, through either acute toxicity attributed to phycotoxins with neurotoxic, haemolytic or cytotoxic effects, or via oxygen depletion caused by decaying blooms (e.g. Boalch 1979; Jenkinson \& Connors 1980; Jones et al. 1982).

Saxitoxin produced by Alexandrium spp. may also be lethal to larvae and juveniles of commercially important finfish and shellfish species, such as Atlantic mackerel (Scomber scombrus) and American lobster (Homarus americanus; Robineau et al. 1991). Biomagnification of saxitoxin in the marine food chain has also been linked to significant fish kills, and both seabird and marine mammal deaths (Pitcher \& Calder 2000; Sephton et al. 2007).

Mariculture. Harmful algal blooms often lead to finfish kills in caged environments, where the fish cannot escape phycotoxins or oxygen depletion from the decaying algal biomass. Risks from HABs are particularly high for finfish confined in sheltered inshore embayments, where the HABs may be concentrated by onshore winds and currents. As an example of this, between 1972 and 1982 in the Seto Inland Sea, Japan, at least 21.8 million cultured yellowtail amberjack (Seriola quinqueradiata) were killed by the raphidophyte Chatonella antiqua (Okaichi 1989). In 1972, the economic loss for the summer outbreak amounted to US $\$ 70$ million. Since then, annual losses have been lower, but recurring severe impacts have continued (Fukuyo et al. 2002). Recurring threats have been reported also from another toxic raphidophyte, H. akashiwo, causing finfish kills in Iceland, Spain, British Columbia and Chile (Landsberg 2002). The losses caused by outbreaks of $H$. akashiwo to wild and net-penned finfish off Puget Sound, Washington, have been estimated to cost in the region of US\$2-6 million per episode. The outbreaks of $H$. akashiwo are believed to have been increasing generally in scope and magnitude in various global regions over the past two decades (Landsberg 2002).

Originating offshore around the UK (Davidson et al. 2009; Shutler et al. 2015), high biomass blooms 
$(>1000$ cells/mL) of Karenia mikimotoi have been increasingly frequent and have been associated with significant finfish kills, including for caged fish in inshore waters (Jenkinson \& Connors 1980; Silke et al. 2005; Davidson et al. 2009). Farmed shellfish including mussels, oysters and clams (Tapes semidecussatta) in the UK and Ireland, and hatchery raised juvenile bivalve spat have also periodically suffered significant mortalities, along with crustaceans and other benthic invertebrates, in conjunction with K. mikimotoi blooms (Raine et al. 2001; Silke et al. 2005).

\section{Evidence of chronic toxicity from HABs in wild fisheries and mariculture}

Symptoms of chronic toxicity in finfish are wide ranging for different HABs. These symptoms include liver pathologies caused by ciguatoxins released from Gambierdiscus spp. and microcystins produced by Microcystis spp., gill pathologies caused by cytotoxins from, for example Prymnesium spp. and Heterosigma spp., narcosis (loss of balance and swimming ability) caused by neurotoxins from Karenia spp. and paralysing saxitoxin from Alexandrium spp., and excess gill mucus production, for example, caused by Chaetoceros spp. (review by Burkholder 1998; Svendsen et al. 2018).

Chronic sublethal effects of HAB toxins in bivalve molluscs include reduction in feeding rates in scallops and oysters (e.g. caused by exposure to Prorocentrum minimum), reduction in growth and byssus production in blue mussels (Mytilus edulis), growth reduction in Eastern oysters (Crassostrea virginica), for example caused by Gymnodinium aurelium/Karenia mikimotoi (Burkholder 1998) and by Alexandrium tamarense ( $\mathrm{Li}$ et al. 2002), reproductive impairment in blue mussels and Bay scallops (Argopecten irradians), for example caused by Chrysochromulina polylepis, reduction in the recruitment of juvenile Bay scallops, for example caused by Karenia brevis (reviewed by Burkholder 1998; Basti et al. 2018). Thus, in addition to toxin accumulation rendering shellfish unsafe for harvesting for human consumption, toxin presence can have a longer term effect, impacting on shellfish abundance and time taken to grow to marketable size. Slower pumping and filtering rates are also likely to increase the time taken to evacuate toxic material from shellfish tissues. Most shellfish species can eliminate phycotoxins within a few weeks, but retention of some toxins (e.g. saxitoxins) in some species, such as sea scallops (Placopecten magellanicus) and Atlantic surfclams (Spisula solidissima), can last up to 5 years (Shumway et al. 1990; Landsberg 2002). Harmful algal blooms also have the potential to impact adversely on the supply of larval 'seed' or 'spat' for aquaculture. Examples of this include Karenia brevis impacting on larval recruitment in Bay scallops (Burkholder 1998), Pacific oysters (Crassostrea gigas) and Northern quahog (Mercenaria mercenaria); (Rolton et al. 2018). For these shellfisheries, the estimated annual economic losses due to K. brevis along Florida's Gulf coast alone are estimated to be up to US\$6 million (NOAA 2004; Adams 2017). Karenia brevisulcata has also been shown to be toxic to larvae of Greenshell mussel (Perna canaliculus), Pacific oyster and New Zealand abalone (Haliotis iris); (Shi et al. 2012).

Consumption of intoxicated finfish and shellfish can also lead to chronic toxicity in organisms higher in marine food chains. For example, domoic acid derived from Pseudonitzschia sp. can cause neuropathic injury in both finfish and shellfish eating mammals and birds (Lefebvre et al. 2007; Ramsdell \& Zabka 2008; Soliño et al. 2019).

\section{Environmental factors contributing to $\mathrm{HAB}$ risk}

\section{Environmental factors promoting HABs}

HABs are natural phenomena within the seasonal cycles of planktonic micro-organisms in aquatic ecosystems (Glibert et al. 2005; Shumway et al. 2018). In recent decades, harmful events appear to be increasing in frequency, duration and impact globally. Verifying them is a research priority (GlobalHAB, 2017; e.g. Wells et al. 2015, 2019). Apparent increased frequencies of HABs may be due to a combination of factors (see Figure 1) including: (i) warming sea surface temperatures, and associated water column stratification and range extensions of tropical organisms, including toxic species; (ii) increased frequency and intensity of storm events and flooding and associated increasing nutrient inputs, upwelling intensities and wider HAB dispersal; (iii) increasing anthropogenic pressures on the marine environment, notably land- and sea-based nutrient enrichment and disturbance of coastal habitats; and (iv) increased awareness and improvements in HAB monitoring systems (Hallegraeff 1993; Raine et al. 2008; Anderson 2012; Bresnan et al. 2013; Wells et al. 2015; Gobler et al. 2017; Anderson et al. 2019).

Evaluating $\mathrm{HAB}$ risk in any 'system' is highly challenging, since environmental drivers include a range of physical, chemical and biological factors, which can combine to influence (i) the initiation/development of a HAB; (ii) its impact/ toxicity and (iii) the termination of a HAB (Roelke \& Buyukates 2001; Anderson et al. 2012a). These factors operate from micro- $(\mathrm{mm})$ to meso- $(10-100 \mathrm{~km})$ to macro $(>100 \mathrm{~km})$ spatial scales and over a range of temporal scales (from seconds to minutes and from days to months; Dickey 2001). For example, an abundant supply of dissolved nutrients, calm sea state, warming, increasing stratification and increased sunlight over a period of weeks may allow the algae to grow in high concentrations, and then, dramatic and significantly increased turbulent sea state (causing increased vertical mixing) over several hours can result in bloom termination (e.g. Shutler et al. 2015). The challenge of 


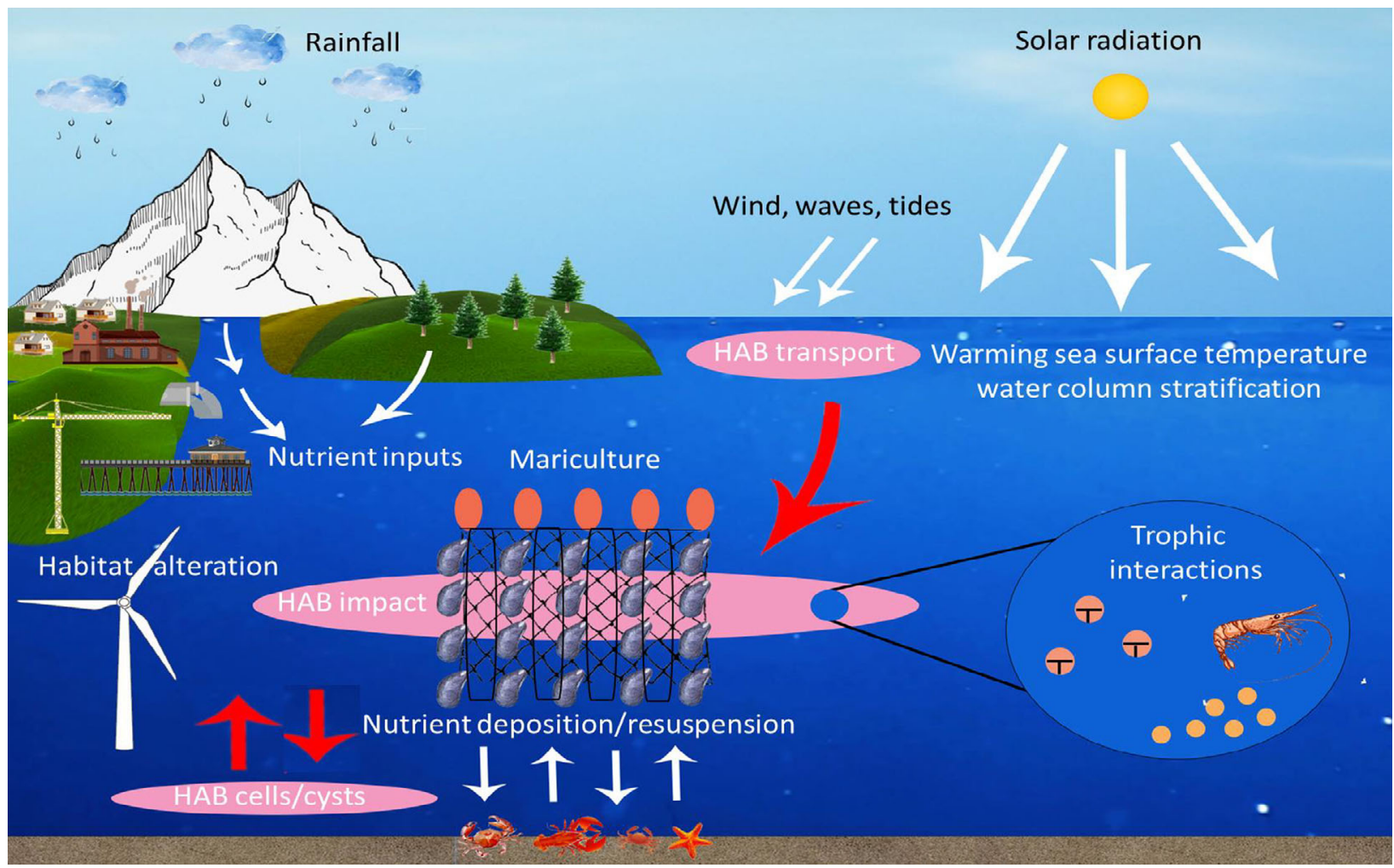

Figure 1 Environmental factors promoting HABs. Complex interactions among environmental factors (solar radiation, wind, waves, tides, rainfall, nutrients), ecological and trophic interactions and biological processes (e.g. cyst formation) can facilitate the proliferation of phytoplankton in general and harmful algal species as well. Excess and unbalanced nutrient supply and habitat alteration can increase the risk of HAB occurrence. HABs negatively impact mariculture production and product quality. (However, some mariculture practices can mitigate the occurrence and impact of HABs, for example, through the use of integrated multitrophic aquaculture approaches; see Figure 2).

understanding $\mathrm{HAB}$ occurrence and toxicity is further complicated by ecological interactions between HAB species and other members of plankton communities, which vary both spatially and temporally in species composition, genetic diversity and physiological status (Anderson et al. 2012a; Davidson 2014). Despite these complexities, some of the key factors driving $\mathrm{HAB}$ dynamics are well characterised and are outlined in sections 'Environmental factors contributing to $\mathrm{HAB}$ initiation and toxicity', 'Environmental factors contributing to HAB termination' and 'Regulation of HABs by filter feeding shellfish' below.

\section{Environmental factors contributing to $\mathrm{HAB}$ initiation and toxicity}

The pre-requisites for any HAB event are the presence of algal cells, spores or cysts; suitable conditions of light and nutrients for their growth and reproduction; and physical conditions that facilitate their accumulation in favourable growing conditions. Cells can accumulate either by horizontal transport (advection) in water bodies by wind and/ or tide, or by resuspension from sediments by wave action, or upwelling of bottom water (e.g. Farrell et al. 2012; Pitcher et al. 2017). The source of propagules that initiate blooms may be local, or distant, though the origin of propagules for any particular harmful bloom is typically difficult to determine. There is evidence that HABs in some areas originate in the ocean, rather than in coastal embayments (Hinder et al. 2011; Whyte et al. 2014; Berdalet et al. 2017; Pitcher et al. 2017). The majority of HABs, including dinoflagellates and diatoms, are holoplanktonic, relying on vegetative cells to survive inhospitable conditions and to seed blooms. In some cases, when growth conditions are suboptimal, highly toxic HABs such as Alexandrium spp. reproduce sexually and form resting cysts. These cysts settle on sediments (Smayda \& Trainer 2010) and then undergo resuspension during storms or coastal upwelling, enabling (re)colonisation of existing and new areas (e.g. Anderson et al. 1994; Pitcher et al. 2017).

Nutrient availability is another key requirement for HAB initiation and maintenance. Most HAB species are primarily photoautotrophs, and their requirements for autotrophic growth include inorganic nitrogen $(\mathrm{N})$, phosphorus $(\mathrm{P})$ and silicate ( $\mathrm{Si}$, in the case of diatoms). 
High-biomass HABs in estuaries and coastal zones have been linked to elevated inorganic nutrient inputs (eutrophication; Rabalais et al. 2010; Paerl et al. 2014) and organic nutrients (e.g. urea from fertilisers, following heavy precipitation and land runoff, Heisler et al. 2008). However, the effects of nutrient inputs may be confounded by many other factors, including natural occurrence of $\mathrm{HABs}$, transport of $\mathrm{HAB}$ species via mariculture and other marine activities, variable meteorological forcing, and longer-term climate change (Callaway et al. 2012; Gowen et al. 2012). There is increasing evidence that many $\mathrm{HAB}$ species can use dissolved and particulate organic forms of $\mathrm{N}$ and $\mathrm{P}$ (through prey ingestion), in addition to autotrophy; this combination of trophic modes is termed mixotrophy (Burkholder 1998; Anderson et al. 2002; Lin et al. 2018). Mixotrophic HAB species are therefore able to proliferate both under high organic $\mathrm{N}$ concentrations and by engulfing prey under nutrient limited conditions. Examples of mixotrophic HAB species include low biomass (100-1000 cells/L) blooming dinoflagellates, such as Alexandrium spp. (Anderson et al. 2012b; Lee et al. 2016) and Dinophysis spp. (Jacobson \& Andersen 1994), and also high biomass (>10 000 cells/L) blooming species such as Pseudo-nitzschia spp. (Loureiro et al. 2008) and A. anophagefferens (Gobler et al. 2011). Furthermore, changes in nutrient ratios (far from the classic stoichiometric Redfield N:P ratio of $16: 1$ ) may be important in stimulating the growth of some HABs and influencing their toxin content (Anderson et al. 2002; Kudela et al. 2010; Glibert et al. 2014a) and responses may be highly species-specific (Wells et al. 2015).

Reduced turbulent mixing and increased thermal stratification are key factors promoting HABs, especially those comprised of dinoflagellates. Water column stratification and nutrient enrichment caused by river plumes, jets, upwelling areas and tidal fronts are also particularly conducive for HAB development (Pitcher et al. 2017). Phytoplankton and other planktonic organisms tend to collect passively in boundary layers in stratified water bodies motile dinoflagellate $\mathrm{HAB}$ species have the added advantage of being able to visit both nutrient-rich deeper water and irradiance-saturated shallower water either side of these boundary layers (e.g. Smayda 1997). HABs are also more likely to occur in sheltered zones of lagoons, estuaries and coasts, as a result of increased water residence times, warmer temperatures and increased penetration of photosynthetically active radiation (PAR; e.g. Smayda 1989). Although strong turbulent mixing may be disadvantageous to bloom development by causing the breakup of chains of individuals and by inhibiting cell division (Estrada \& Berdalet 1997), low level turbulence can enhance nutrient availability by facilitating increased transfer of molecules in or out of plankton cells, especially in passively floating diatoms (Peters et al. 2006). Other biological processes, including inter-cell quorum sensing and encounter rates with competitors and grazers (Gowen et al. 2012), are also modulated by fine scale turbulence and this can also favour HABs (e.g. Berdalet et al. 2017).

\section{Environmental factors contributing to $\mathrm{HAB}$ termination}

Advection and dispersion of HABs, increasing turbulent shear forces breaking up cells, and/or nutrient limitation are all understood to contribute to the termination of HABs (Gentien et al. 2007; Lenes et al. 2013), and consequently, HAB prediction models are often driven by these physical processes and biogeochemical fluxes. However, models that only include these processes often 'over-predict' $\mathrm{HAB}$ duration, indicating that inter-species biotic interactions play important roles in terminating harmful blooms (Roelke \& Buyukates 2001; Lenes et al. 2013; Davidson et al. 2016).

Plankton grazers or predators play an important role in regulating the abundance of marine planktonic micro-algae, including $\mathrm{HAB}$ species. In nutrient limited (oligotrophic) offshore marine environments, mesozooplankton (e.g. copepods $0.2-20 \mathrm{~mm}$ ) consume $10-40 \%$ of marine phytoplankton, while micro-zooplankton (20$200 \mu \mathrm{m}$ ) consume around 60-70\% (Calbet 2008). In temperate nutrient-rich (eutrophic) upwelling and estuarine ecosystems, micro-sized heterotrophic and mixotrophic dinoflagellates (including HAB species) can dominate phytoplankton grazing (Calbet 2008). More detailed, mechanistic understanding concerning how and to what extent grazers regulate or terminate HABs is lacking. Plankton community interactions can vary markedly in temperate waters displaying a seasonal succession of different blooming species and also in (sub)tropical waters with relative constant standing stocks of microplankton. In both cases, food web dynamics can alternate between resource (bottom-up) and predatory (top-down) control (Calbet 2008) and outcomes for HABs are highly situation-specific (Turner \& Tester 1997).

Marine parasitic microbes (micro- and nano-sized protists $10-100 \mu \mathrm{m}$, pico-sized bacteria $0.2-10 \mu \mathrm{m}$ and femtosized viruses $\leq 0.1 \mu \mathrm{m}$ ) target all of the main phytoplankton groups (Gachon et al. 2010). They have been shown to play a significant role in terminating some major algal blooms (Wilson et al. 2002) and have also been linked to the decline of HABs (Chambouvet et al. 2008; Roth et al. 2008; Jones et al. 2011). In turn, this has prompted research into the microbial control and bioremediation of HABs (Brussaard 2004; Sun et al. 2018; see section 'Spatial and temporal planning to minimise $\mathrm{HAB}$ risk'). Larger micro-sized parasites such as the dinoflagellate Amoebophyra spp. may also be responsible for the termination 
(Rosetta \& McManus 2003; Montagnes et al. 2008) or regulation (Nishitani et al. 1985) of dinoflagellate HABs such as Alexandrium spp.

Adaptive responses in $\mathrm{HAB}$ species to avoid or combat grazers and parasites include sensing and moving away from grazers (Wolrhab 2013); adapting/optimising colony size (chain length) versus swimming speed (Selander et al. 2012); synthesising and releasing phycotoxins and/or other allelochemicals (Stüken et al. 2011; Anderson 2012); undergoing or prolonging encystment (Rengefors et al. 1998; Toth et al. 2004); and undergoing auto-lysis (i.e. programmed cell death) (Franklin et al. 2006; Lenes et al. 2013). Combinations of mechanisms underlying predatorprey and host-parasite interactions can vary greatly since algal prey/host and predator/parasite niches are highly species-specific (Amin et al. 2015; Ramanan et al. 2016).

\section{Regulation of HABs by filter feeding shellfish}

Filter-feeding shellfish can exert considerable (top-down) grazing pressure, limiting phytoplankton (and zooplankton) biomass, particularly in shallow, well mixed estuaries and coastal waters, where bottom-living bivalves can come into contact with and filter the majority of the water column (Newell 2004; Lucas et al. 2016). Bivalves such as mussels, suspended on ropes hanging vertically in the water column can also be effective at filtering plankton at deeper water sites (Stadmark \& Conley 2011; Hedberg et al. 2018). Physical factors such as water column exchange, turbulent mixing, temperature and stratification, and the influence of mariculture infrastructures on each of these (see Section 'Physical alteration of habitats and hydrodynamic regimes'), can be important in modulating shellfish grazing, phytoplankton sinking, and phytoplankton community composition - for example reduced vertical mixing favours motile dinoflagellates, while nonmotile phytoplankton such as diatoms sink below the euphotic zone and are more easily intercepted by grazers (Lucas et al. 2016). The influence of selective filter feeding by shellfish on plankton community structure, including $\mathrm{HABs}$ species, is relatively poorly understood (Newell 2004; Petersen et al. 2008; Lucas et al. 2016). Simple size selection for nano-sized plankton and above $(>4 \mu \mathrm{m})$ and higher filtration rates in the warmer summer months may serve to reinforce seasonal succession from nano- to pico-plankton dominated communities (Newell 2004). Sensing of food particles and their surface chemistry have been suggested to play a role in selective filtering of nutritious plankton in preference to detrital and mineral particles (Ward \& Shumway 2004; Espinosa et al. 2009; Yahel et al. 2009). Phycotoxins, particularly paralytic shellfish toxins (PSTs) as well as other toxin classes (e.g. NSTs and ASTs), are capable of inducing valve closure and/or reducing filtration rate in bivalves, as well as impairing growth and reproduction and inhibiting byssus production (Burkholder 1998; Landsberg 2002; Manfrin et al. 2012). Nevertheless, some bivalves show preferential uptake of harmful algal cells. This has been shown in the laboratory in five bivalve species (Bay scallop, Eastern oyster, Northern quahog, softshell clam (Mya arenaria) and the blue mussel (Mytilus edulis). All bivalves, with the exception of softshell clam, ejected intact cells of three HAB species (Prorocentrum minimum (PST and DST), Alexandrium fundyense (PST) and Heterosigma akashiwo (NST)) in their faeces or pseudo-faeces. Only oysters exposed to $H$. akashiwo showed partial or complete valve closure and reduction in filtration rate. These results confirm that feeding responses of bivalves in the presence of $\mathrm{HABs}$ can be highly species-specific. Furthermore, clearance of HABs from the water by bivalves may simply result in the transfer of intact/live cells to the sediment, from which they could be resuspended (Hégaret et al. 2007).

\section{Environmental impacts of mariculture and contribution to $\mathrm{HAB}$ risk}

Long-term time-series data are required to demonstrate the influence of finfish, shellfish and/or macro-algal mariculture on $\mathrm{HAB}$ risk as recognised in the Science Plan of the international programme on HABs (GlobalHAB, 2017). Accumulating evidence from China, which has the longest running, largest and highest concentration of mariculture in the world, indicates that the frequency and extent of HABs has been increasing concurrently with the industry growth since 1960 (Wang et al. 2008; Lu et al. 2014; Wartenberg et al. 2017). The occurrence of HAB events in China increased sharply in 2009 with $\sim 80$ episodes, covering $>15,000 \mathrm{~km}^{2}$ of China's coastline in just one year. The increasing trend, however, also follows increasing urbanisation of coastal fringes (Liu \& Su 2017). Potential environmental effects of mariculture are listed in Table 3, and the tendencies for these effects to promote $\mathrm{HAB}$ formation and impact (either directly or indirectly) are discussed in sections 'Nutrient emission versus assimilation', 'Chemical treatments used to control pathogens and parasites', 'Escapees and introduction of invasive and/ or harmful species', 'Physical alteration of habitats and hydrodynamic regimes' and 'Transmission of HAB species and alteration in the abundance and composition of plankton communities'.

\section{Organic and inorganic nutrient emission versus assimilation}

Nutrient emissions from mariculture operations are predicted to increase substantially due to industry expansion (up to sixfold by 2050). The majority of these emissions 
Table 3 Environmental effects of mariculture that can promote $\mathrm{HAB}$ risk

(i) Organic and inorganic nutrient emission versus assimilation;

(ii) Disease and use of preventative chemical agents;

(iii) Escapees and genetic interactions with wild populations;

(iv) Physical alteration of habitats and hydrodynamic regimes;

(v) Increase in HAB transmission (between relay sites) or alteration of the abundance and composition of plankton communities.

References for (i-iv): Lovatelli et al. (2013), Kapetsky et al. (2013), Wartenberg et al. (2017).

References for (v): Gibbs (2004), Grant et al. (2007).

comprise nutrient waste, primarily from finfish (fed mariculture) and also from shellfish, released in a dissolved form directly to the water column (Bouwman et al. 2013). These nutrient emissions may promote the growth of harmful algal species in the vicinity of mariculture farms (Anderson et al. 2002; Hallegraeff 2003). However, causal linkages between fish farming and eutrophication (Pitta et al. 2005; Modica et al. 2006) and HABs (Anderson et al. 2008) are often not clear (Smayda 2004; Gowen et al. 2012). In some cases (e.g. farming of extractive shellfish), mariculture can cause net assimilation of nutrients leading to deficits (Ferreira et al. 2014), while elsewhere nutrient emissions may exceed local environmental assimilation capacities (Bouwman et al. 2013). Problems are likely to be more acute for farms with higher stocking densities (Sellner et al. 2003; Bouwman et al. 2013). Intensive bivalve cultivation can alter the nitrogen:phosphorus $(\mathrm{N}: \mathrm{P})$ nutrient stoichiometry and change the major $\mathrm{N}$ species to reduced forms, especially ammonia, as well as particulate organic nitrogen, and these $\mathrm{N}$ forms are preferred by various harmful algae - predominated by dinoflagellates (e.g. Arzul et al. 2001; Glibert et al. 2014a, but see Davidson et al. 2012). Conversely, diatoms have also been shown to decline as a result of nutrient excretion by bivalves (Lucas et al. 2016). A further concern arises because of low assimilation efficiencies (typically 30-40\% for $\mathrm{N}$, or less under bloom conditions), such that shellfish can become point sources of regenerated nutrients. Benthic regeneration of the accumulated faeces and decomposing feed can be significant in shallow well mixed coastal waters (Bouwman et al. 2013).

\section{Disease and use of chemical treatments to control pathogens and parasites}

Infections by pathogens and infestations of parasites, exacerbated by aggregations of wild fish around mariculture installations (Dempster et al. 2004), present a risk to human and (shell)fish health and have similar financial impacts to those for HABs (e.g. impacts of white spot virus on shrimp farming in Southeast Asia $\sim 6$ US\$ billion/year) (Lafferty et al. 2015). Consequently a range of antimicrobial chemicals and pesticides are licensed for use in mariculture, specifically for finfish culture (Johnston \& Santillo 2002; Read \& Fernandes 2003). Cumulative environmental exposures to these chemicals can be significant in some coastal waters (Baker-Austin et al. 2008; Uyaguari et al. 2013) and may exceed environmental quality standards (EQSs), which can be as low as 1 part in 1 trillion for some highly potent compounds (Gilliom 2007; Watts et al. 2017). Impacts of antimicrobial chemicals on beneficial microbes and associated ecosystem services (e.g. nutrient cycling, water quality and $\mathrm{HAB}$ regulation) could be significant (Woolhouse \& Ward 2013; Watts et al. 2017). Research on the impacts of chemicals on HAB regulation has been extremely limited to date and has generally focused on the effects of pesticides on HABs in freshwater systems (Relyea 2009; Beketov et al. 2013; Harris \& Smith 2015; Staley et al. 2015).

\section{Escapees and introduction of invasive and/or harmful species}

Macro-algal blooms (seaweed blooms) leading to oxygen depletion, alteration of ecosystem biodiversity and production of certain toxins (Anderson 2009) have been shown to originate from open water suspended culture systems. For example, significant escapes may occur from Porphyra culturing spanning more than $40000 \mathrm{~km}^{2}$ in some instances in the South China Sea. Bloom-forming species including sea lettuce (Ulva spp.) and gutweed (Enteromorpha spp.) can cause major economic loss by inundating waterways and beaches, leading to widespread asphyxiation of organisms when the blooms biodegrade (Liu \& Su 2017).

\section{Physical alteration of habitats and hydrodynamic regimes}

Reduced hydrodynamic flows are known to lead to reduced turbulence, which in turn tends to promote the blooming of dinoflagellate species, including HAB species (Smayda \& Reynolds 2001). Mariculture structures, including longlines for shellfish and kelp and net pens for finfish can significantly change surface current speed and direction, induce down-welling, increase stratification and reduce water exchange in sheltered and enclosed bays (Zeng et al. 2015; Lin et al. 2016; Wartenberg et al. 2017). Expansion of suspended mariculture in Sanggou Bay reduced the average speed of currents by $40 \%$ and the average half-life of water exchange was prolonged by $\sim 70 \%$ (Shi \& Wei 2009). It is also possible that disturbance of sediments by aquaculture and fishing operations may promote the resuspension of HAB cysts. 
Transmission of HAB species and alteration in the abundance and composition of plankton communities

Risks of $\mathrm{HAB}$ impacts may increase directly with the future expansion of mariculture, via the movement (relaying) of 'contaminated' shellfish stocks and equipment between sites (Hégaret et al. 2008), including from the coast to offshore and vice versa, or via regular aquaculture operations and ballast water transfers (Hallegraeff \& Bolch 1991, 1992). Indirect impacts include alteration of the abundance and composition of plankton communities, including $\mathrm{HAB}$ competitors, parasites and grazers (Roth et al. 2008; Eckford-Soper et al. 2016). Over-intensification of mariculture can also lead to depletion of planktonic larvae (including finfish, shellfish and other invertebrates) and reduced food availability for wild shellfish populations (Gibbs 2004; Ferreira et al. 2014; Pastres et al. 2018), especially in regions with low primary productivity (Gibbs 2004; Grant et al. 2007). This may have consequences for negative feedback control of the abundance and composition of plankton communities by native filter feeders.

\section{Detecting and forecasting $\mathrm{HAB}$ events}

Maximising the profitability and environmental sustainability of mariculture requires surveillance monitoring and early warning systems, forecast-based financing and strong risk governance structures (FAO, IFAD, UNICEF, WFP and WHO, 2018). The following systems are outlined in sections 'In situ monitoring', 'Satellite remote sensing (Earth observation)' and 'Predictive modelling' below.

\section{In situ monitoring}

In situ monitoring for $\mathrm{HAB}$ species abundance and phycotoxin concentrations in (shell)fish is the principal method for 'official control' monitoring and safeguarding of food fish safety for human consumption in Europe, North America, Asia and Australasia. In situ monitoring is generally conducted via the collection and analysis of representative field samples; using microscopic analysis for phytoplankton identification and enumeration, and using mass spectrometric analysis for phycotoxin identification and quantitation. The use of autonomous in situ molecular (qPCR) and flow cytometry methods has also proved capable of real-time sensing of algal blooms (e.g. Campbell et al. 2013). These in situ devices can be located on smart buoys or underwater gliders (Davidson et al. 2014). Integrative solid-phase adsorption toxin tracking (SPATT) deployed in the field for the passive sampling of algal toxins has also been validated recently, and improved enzyme-linked immuno-sorbent assay (ELISA)-based methods with lower detection limits for more toxins have become commercially available for both screening and routine monitoring purposes (Zhang \& Zhang 2015).

In Europe, routine $\mathrm{HAB}$ monitoring (EU Directives $2000 / 60 / \mathrm{EC}$ and $2006 / 113 / \mathrm{EC}$ ) is used to quantify HAB species abundance and phytotoxin levels (Higman et al. 2014). Shellfish toxin concentrations are evaluated against EU action levels triggering harvesting bans (ASP $>20 \mathrm{mg}$ Domoic/epi-Domoic acid; PSP $>800 \mu \mathrm{g}$ STX equivalents (eq.); Lipophilic toxins (DSP) OA/DTXs/PTXs together $>160 \mu \mathrm{g}$ OA eq.; AZAs $>160 \mu \mathrm{g}$ AZA eq.; YTXs $>3.75 \mathrm{mg}$ YTX eq. - see Table 2 and underlying text for expansion of abbreviations), allowing for cross-border trade of aquaculture products. While individual HABs and their toxins vary in concentration on a seasonal basis, HAB events can occur year-round, as can aquaculture harvesting. Responsibility for 'official control' resides with respective statutory authorities within EU member countries and results are published online for each designated site. In situ HAB monitoring data can be combined with satellite imagery (Section 'Satellite remote sensing (Earth observation)') and numerical models (Section 'Predictive modelling') to give a better indication of $\mathrm{HAB}$ risk, as implemented in Ireland (Leadbetter et al. 2018). In some cases, more proactive monitoring can occur, such as in Scotland where a group of finfish farmers collectively pay for weekly satellite remote sensing observations of Karenia mikimotoi surface distributions (Davidson et al. 2016).

In the United States, both the National Oceanic and Atmospheric Administration (NOAA) and the Environmental Protection Agency (EPA) monitor for, and provide some indication of, impending HABs. In the Gulf of Mexico, a twice-weekly risk assessment is provided during the summer-autumn HAB season, based on a regular in situ monitoring programme (and using meteorological models, particularly to provide warning of toxic aerosol events, e.g., caused by Karenia brevis). The rest of the US coastline is monitored routinely for $\mathrm{HAB}$ events by a volunteer network; the 'National Phytoplankton Monitoring Network', sampling twice monthly. In some locations in the United States, more intensive programmes are in place, such as the SoundToxins programme which is funded by NOAA and Washington Sea Grant and monitors 31 sites on a weekly basis in Puget Sound in Washington State, or the California Harmful Algal Bloom Monitoring and Alert Program (CalHABMAP) funded by US Congress and the National Aeronautics and Space Administration (NASA; Kudela et al. 2015). 
Across Southeast Asia, some countries operate a regular programme of shellfish monitoring (e.g. Japan, Indonesia, Vietnam, Korea), while other countries lack the resources to have a robust programme or initiate sampling when blooms are detected (e.g. Laos, Myanmar; Eong \& Sulit 2015). In Australasia, monitoring effort varies, with frequent sampling of high risk locations in western Australia (Dias et al. 2015), but overall being less well sampled and leading to high instances of human poisonings (Hallegraeff et al. 2017). In Chile and wider Latin America, after many intoxication events, a standardised sampling programme was developed across the region in 2009, although maintaining the network and regular sampling is dependent on continued resource availability (Cuellar-Martinez et al. 2018).

In scaling up from regional monitoring to a Global Ocean Observing System (GOOS) for HABs, it is recognised that there is no universal 'one-size-fits-all' solution, but that communication is key and stakeholders require affordable, easy to understand, real-time information, for example, in the form of spatial and temporal risk mapping (Anderson et al. 2019).

\section{Satellite remote sensing (Earth observation)}

The use of satellite remote sensing, alongside in situ sensing or ground truthing, has wide-scale potential for detecting increases in potential surface dwelling HAB species or high concentrations of all surface algae (reviewed by IOCCG, 2014; Davidson et al. 2016) in relation to fisheries and aquaculture/mariculture (IOCCG, 2009). Images of ocean colour from visible and infrared spectrum wavelengths can be correlated statistically with HABs events or in some cases the HAB species can be observed if they are spectrally distinct (https://www.shelleye.org/index; https://www.s3euro hab.eu/en/). For example, correlations have been found between ocean colour, chlorophyll and algal biomass (Sourisseau et al. 2016), with some correlations incorporating the use of artificial neural networks (El-Habashi et al. 2017). K. mikimotoi and K. brevis are both species that have spectral signatures that allow successful identification when they are present in large abundances (Kurekin et al. 2014; Shutler et al. 2015; El-Habashi et al. 2017). In general, HAB species that are detectable by remote sensing are those that form significant blooms of $>1000$ cells $/ \mathrm{mL}$ at the sea surface or near-surface (e.g. Karenia mikimotoi, Kurekin et al. 2014; Karenia brevis, El-Habashi et al. 2017). Satellite imaging however cannot detect species that form harmful blooms at greater depths or at low densities of $\sim 100$ cells/L (e.g. Dinophysis spp.) (Reguera et al. 2014). Remote sensing techniques are also unable to detect HABs when observation of ocean colour is obscured by cloud cover (Maguire et al. 2016).

\section{Predictive modelling}

Early warning of the onset of HAB events over time scales of several days, and their likely movement and changing magnitude (i.e. relative to safe limits), would be highly beneficial to the mariculture industry, allowing proactive, rather than reactive, responses to minimise impacts on businesses, customer confidence or human health (Davidson et al. 2016). Immediate responses may include advanced (or delayed) harvesting of stock (limited by storage capacity and by supply chain logistics) or deployment of mitigation measures (Section 'Analysis of options for mitigating $\mathrm{HAB}$ risk to mariculture'). Longer-term, more strategic business planning is dependent on knowing when harvesting bans imposed by $\mathrm{HAB}$ outbreaks are likely to be lifted, in order to better manage business operations, staffing and supply chains. HAB predictions based on readily available physical (hydrographical and meteorological) data offer a simple, tractable solution for forewarning mariculture operators in locations where these physical 'forcing factors' are principle drivers of HAB initiation. These physical models are generally better at predicting $\mathrm{HAB}$ initiation than $\mathrm{HAB}$ termination, but in any event forecasting is generally limited to 1 week in advance (Davidson et al. 2009; Cusack et al. 2016; Schmidt et al. 2018), which corresponds with general extent and accuracy of meteorological forecasting (Davidson et al. 2016). Furthermore, the majority of models, which are driven predominantly by meteorological and hydrographical processes, often 'over-predict' HAB duration (Davidson et al. 2016). This is reassuring for human safety, but not so appealing for businesses desperate for harvesting bans to be lifted, as soon as it is safe to do so. Hydrophysical models coupled with HAB population models, which also incorporate biological and geochemical processes, can improve $\mathrm{HAB}$ predictions, by taking into account life-history data and environmental and physiological optima for HAB species (Roelke \& Buyukates 2001; McGillicuddy et al. 2005; Glibert et al. 2014b; Aleynik et al. 2016; Gillibrand et al. 2016). Modelling changes in trophic mode (autotrophy versus mixotrophy) (Lee et al. 2016) and interactions with other plankters, including $\mathrm{HAB}$ parasites and grazers (Lenes et al. 2013) can also help to improve predictions of bloom duration. However, increasing trophic complexity in community and ecosystem models can lead to reduced resolution of species-specific dynamics, including HAB population dynamics (Flynn \& McGillicuddy 2018). Other trade-offs in implementing more elaborate ecosystem models include greater specificity (spatial limitation) of model predictions and increasing requirements for input data for model parameterisation, computational processing power and expert operators (Butenschön et al. 2016). 
Combining bio-physical modelling of HABs with satellite remote sensing data has been used successfully in shortterm national forecasting systems for public health and aquaculture protection in the US and EU for example (Kudela et al. 2015; Shutler et al. 2015; Davidson et al. 2016; Ruiz-Villarreal et al. 2016) with the potential for wider detection of HABs (Anderson et al. 2019). There is also the potential to extend forecasting of $\mathrm{HAB}$ events from days to several weeks or even months in advance, by tracking successional changes in plankton community composition over time, in conjunction with traditional in situ monitoring and real-time sensing of impending blooms (Roelke \& Buyukates 2001; Campbell et al. 2013). Inter-annual predictions of $\mathrm{HAB}$ trends and the identification of hotspots prone to recurring $\mathrm{HAB}$ events are also highly beneficial for strategic marine spatial planning, including for new or expanding mariculture infrastructure. These longer-term predictions are more circumspect, as the biogeographical niches of different $\mathrm{HAB}$ genera or species are likely to shift with a changing climate and/or become more variable (Callaway et al. 2012; Wells et al. 2015; GlobalHABs, 2017).

\section{Analysis of options for mitigating HAB risk to mariculture}

Options for mitigating $\mathrm{HAB}$ impacts to mariculture fall into three basic categories: (i) spatial and temporal planning of mariculture operations to avoid or minimise the risk of HABs; (ii) holistic environmental management options to minimise local $\mathrm{HAB}$ risk around mariculture farms (e.g. multi-species, multi-trophic, ecosystem-based options favouring nutrient assimilation and recycling and/ or cultivation of species which are more resistant to, or less prone to accumulate, $\mathrm{HAB}$ toxins); (iii) direct interventions for controlling the presence or abundance of HAB species (physical, chemical, biological control options). The advantages of various options in each of these categories and their state of readiness for application in commercial mariculture are discussed below (Sections 'Spatial and temporal planning to minimise HAB risk', 'Holistic environmental management options for minimising $\mathrm{HAB}$ impacts' and 'Direct interventions for controlling HAB impacts').

\section{Spatial and temporal planning to minimise HAB risk}

Spatial planning for new mariculture infrastructure can be targeted to avoid HAB hotspots, while planning harvesting outside peak $\mathrm{HAB}$ risk periods can be implemented at already established/licensed mariculture farms, with both options being informed by existing $\mathrm{HAB}$ detection and forecasting systems (outlined in Section 'Detecting and forecasting $\mathrm{HAB}$ events'). Development of offshore sites with significant exposure to tides, wind and wave action (Drumm 2010; Froehlich et al. 2017; Buck et al. 2018) can potentially mitigate $\mathrm{HAB}$ risks linked to mariculture itself e.g. elevation of nutrient levels, physical alteration of habitats and hydrodynamics and modification of local planktonic (and benthic) communities (Section 'Environmental impacts of mariculture and contribution to $\mathrm{HAB}$ risk'). However, HABs often originate naturally offshore (independently from anthropogenic activities) (Whyte et al. 2014; Davidson et al. 2016; Díaz et al. 2016; Gobler et al. 2017) and there is some evidence that some HAB species may present even greater risk here compared to inshore areas (Trainer et al. 2012). Regulatory policy for sustainable offshore aquaculture has only recently been developed in the United States (NOAA, 2016) and is not yet formulated and published in other countries or continents, such as New Zealand, Australia and Europe (Froehlich et al. 2017). Emerging guidelines for assuring minimal impacts from offshore mariculture on water quality and pelagic and benthic communities relate to: minimum water depths (twice the depth of mariculture infrastructure) and minimum water flow rates $(>0.05 \mathrm{~m} / \mathrm{s}$ ) (Belle \& Nash 2008; Froehlich et al. 2017). In such localities, the probability of ecological effects on neighbouring natural habitats diminishes significantly beyond a distance of $90 \mathrm{~m}$ (Froehlich et al. 2017). This distance also provides a nominal guideline for the proximity/density of neighbouring offshore mariculture infrastructure. However, some ecosystem models predict significant trophic interactions between large offshore installations and more distant coastal mariculture sites, indicating wide-ranging implications for nutrient budgets and biosecurity (spread of microbial pathogens). These ecological interactions have been modelled and verified for the large $\left(15 \mathrm{~km}^{2}\right)$ Ria Formosa Mariculture Park located $>3 \mathrm{~nm}$ offshore from coastal sites in the Algarve region of Portugal (Ferreira et al. 2014). Ecological linkages between extensive mariculture installations and the periodic occurrence of HABs along the Algarve coast have yet to be established.

\section{Holistic environmental management options for minimising $\mathrm{HAB}$ impacts}

Holistic environmental management of HABs addressing causative factors (e.g. minimising nutrient inputs from landbased sources and from mariculture itself) or preserving habitats and ecosystem services that help regulate HABs, may be simpler, more effective and more environmentally friendly (WHO, 2003; Wells et al. 2019) than attempting to control $\mathrm{HAB}$ outbreaks directly (Section 'Direct interventions for controlling $\mathrm{HAB}$ impacts'). For example, nutrient enrichment can be managed through the use of 'extractive' shellfish and macro-algal species. Furthermore, restoration of coastal 
habitats, for example with seagrasses that harbour algicidal bacteria (Inaba et al. 2019), or cultivation of seaweeds that secrete algicidal chemicals (Zerrifi et al. 2018), can also help mitigate against HABs. This follows Ecosystem Approaches to Fisheries and Aquaculture (EAF/EAA) (Soto \& AguilarManjárrez 2009; FAO, 2018), which cover three main aspects: (i) minimising environmental impacts and waste; (ii) sustaining wider ecosystem functions and services; and (iii) promoting human well-being and equity among marine stakeholders.

(i) Minimising environmental impacts and waste - Shellfish and macro-algal culturing can have a positive influence on the regulation of $\mathrm{HABs}$, either by reduction of high biomass blooms through filter feeding or via nutrient removal (Stadmark \& Conley 2011; Petersen et al. 2014). Nutrient removal by mariculture, curbing eutrophication, in EU coastal waters alone is valued at US\$20 to 30 billion per year (Ferreira et al. 2009). Furthermore, mariculture reduces the exploitation of natural shellfish stocks, which can also help regulate HABs. For example, overfishing of shellfish around Long Island, USA, has coincided with the increased occurrence of Aerococcus anophagefferens brown tides (Glibert et al. 2005).

(ii) Sustaining wider ecosystem functions and services Mariculture farms can provide sheltered nursery habitats for marine/estuarine organisms, with the potential to enhance local fisheries and to support biodiversity in neighbouring marine protected areas (Le Gouvello et al. 2017). Maintaining biodiversity is important, since impoverishment of planktonic species and reduced species succession have been correlated with increased $\mathrm{HAB}$ risk. In some cases, such community changes can forewarn HAB outbreaks several months before the detection of the HAB species (e.g. Microsystis sp.; Roelke \& Buyukates 2001).

(iii) Promoting human well-being and equity among marine stakeholders - Marine spatial planning is required to effectively locate mariculture and fisheries conservation areas and avoid conflicts with other uses of the marine environment. To facilitate planning, environmental models can be used to assess nutrient budgets, productivity versus eutrophication risk, the risk of transmission of pathogens, pests associated with mariculture (Ferreira et al. 2014; Pastres et al. 2018) and the risk of advection of HABs to mariculture sites (Dabrowski et al. 2016; Paterson et al. 2017).

A promising approach for delivering on each of these EAA/EAF aspects, including the potential to minimise $\mathrm{HAB}$ risk, is integrated multi-trophic aquaculture (IMTA) (Wartenberg et al. 2017). IMTA employs cultureable 'extractive' species (e.g. suspended bivalve shellfish and macroalgae, and benthic deposit feeders) to remove/reuse waste nutrient material discarded from the culturing of 'fed' species (finfish and crustaceans) thereby providing a self-sustaining and more productive food web (Figure 2)
(Soto 2009; Troell et al. 2009; Chopin et al. 2012). Macroalgae can also play a direct role in inhibiting the growth of microalgae, including $\mathrm{HAB}$ species, through competition for nutrients (Soto 2009; Holdt \& Edwards 2014), inhibitory allelopathy (Tang \& Gobler 2011; Ben Gharbia et al. 2017; Zerrifi et al. 2018), and/or by reducing light penetration (Zhou et al. 2006; Wang et al. 2007; Yang et al. 2015).

Further developments in IMTA, including deploying aquaculture species that are less sensitive to, or less likely to accumulate, toxins from locally re-occurring $\mathrm{HAB}$ species, are likely to be required to maximise benefits in terms of mitigating against $\mathrm{HAB}$ impacts. The long-term sustainability of IMTA for mitigating HAB risk with climate change also requires further research (Wells et al. 2019). For example, China has some of the world's largest and longest established IMTA systems, including a multi-trophic system established in 1996 in Sanggou Bay, Yellow Sea (Fang et al. 2016). Since 2010, however, Sangou Bay has regularly experienced brown tides of $A$. anophagefferens (Kong et al. 2012). Coincidentally, large-scale A. anophagefferens brown tides extending over $3000 \mathrm{~km}^{2}$ have occurred in the north western Bohai Sea each year in early summer since 2009 and have caused significant negative impacts on scallop (Argopecten irradians) culture (Zhang et al. 2012). Other HAB species including Karenia mikimotoi and Prorocentrum donghaiense also continue to form annual blooms in nearshore waters of the Yellow Sea and neighbouring East China Sea (Li et al. 2009), with K. mikimotoi causing substantial losses to mariculture from 2005 to 2015 (Liu \& Su 2017).

\section{Direct interventions for controlling $\mathrm{HAB}$ impacts}

Physical and chemical control methods can remove HABs efficiently and are used operationally as a last resort in mariculture, but they can be costly, lack specificity to HABs, and are generally less effective in coastal situations in comparison with enclosed or semi-enclosed aquatic systems. Alternatively, biological control methods can be potentially more specific for individual $\mathrm{HAB}$ species, minimising impact on other non-target species, but they are more difficult to constrain in non-enclosed systems and have not progressed beyond laboratory or field trials for mariculture applications (reviewed in NOAA, 2015; Sellner \& Rensel 2018; Sun et al. 2018; Gallardo-Rodríguez et al. 2019).

Physical control methods include the use of barriers or skirts, for example, around fish net pens and/or the removal of $\mathrm{HAB}$ cells by water column mixing, filtering, flocculation, settlement, sediment burial and dredging, or HAB cell lysis using ultrasound (Sellner \& Rensel 2018). Water column mixing using water or air pumping systems leads to disruption of thermal stratification and impairment of algal buoyancy or alteration of their daily 


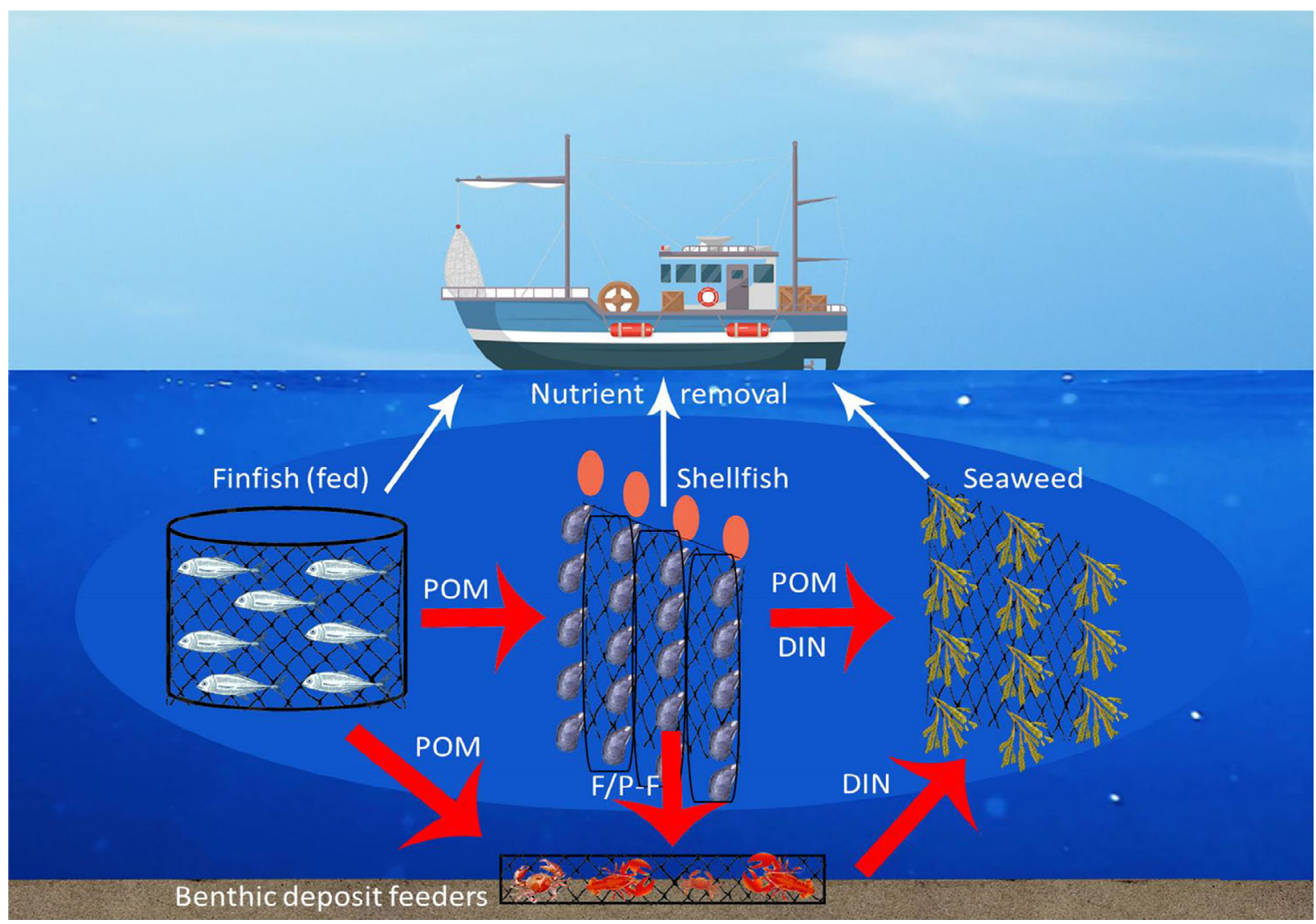

Figure 2 Integrated multi-trophic aquaculture (IMTA). POM - particulate organic matter; DIN - dissolved inorganic nitrogen; F/P-F - faeces/pseudofaeces. IMTA incorporating suspended filter-feeding shellfish, and benthic deposit feeding shellfish can reduce the proliferation of HABs and recycle POM (capable of fuelling HAB growth) associated with 'fed' species (finfish and crustaceans). Suspended macroalgae can also reduce the growth of microalgae, including HAB species, through shading, competition for nutrients (e.g. fine POM and DIN) and inhibitory allelopathy.

migration patterns, removing them from the photic zone and preventing photosynthesis. Direct cell removal from the water column can be achieved by hydrodynamic separation, centrifugation, pump filtration, plankton net trawling or membrane filtration. A measure which has proven effective for HAB control in the open sea has been the use of clays to induce bloom flocculation. As considerable quantities of clay are needed, from 100 to $400 \mathrm{~g} / \mathrm{m}^{2}$ (Park et al. 2013), physical resuspension of local sediments or importation on ships are a practical solutions. Subsequent flocculation, sinking and burial of HAB cells and/or cysts can be followed by dredging and physical or chemical treatment before discharging the sediments back to the removal site (NOAA, 2015; Sellner \& Rensel 2018). Potential drawbacks include the removal of non-harmful algae. More efficient flocculation can be achieved by spraying the sea surface with modified clays containing inorganic (e.g. aluminium sulphate or polyaluminium chloride) or organic (e.g. polyacrylamide or chitosan) modifiers, which can be up to 100 times more efficient in adsorbing HAB cells (and other plankters) than natural clay sediments. This enables a reduction in application levels and time windows - reducing the risk of clay build-up and helping to reduce impacts on non-blooming (non-HAB) species (reviewed in Gallardo-Rodríguez et al. 2019). Furthermore, modified clays have been shown to kill HAB cells (Beaulieu et al. 2003), adsorb and remove extracellular HAB toxins (Pierce et al. 2004; Seger et al. 2015, 2017) and particulate nutrients (Yu et al. 2017), and to also reduce HAB toxin accumulation in benthic filter-feeding bivalves (Yu et al. 2017). Consequently, they have been used in Japan (Shirota 1989) and employed as a standard method for controlling HABs in China, since 2014 (Yu et al. 2017). A remaining concern, preventing uptake of these physical control methods in other countries, is their lack of specificity for controlling harmful species and possible unknown impacts on other phytoplankton and the ecosystem as a whole.

More direct chemical treatments for controlling HABs include the use of natural biosurfactants, biocides or allelochemicals (e.g. biochemical extracts from macroalgae), or 
the use of synthetic chemicals, including hydrogen peroxide and isolated algicidal compounds, or metallic compounds such as copper sulphate. These various chemicals (metals and organic compounds) can interfere with $\mathrm{HAB}$ cell survival (algicidal chemicals), growth and reproduction (algistatic chemicals) through a variety of mechanisms (NOAA, 2015; Gallardo-Rodríguez et al. 2019). Biochemicals are advantageous in terms of their higher diversity, biodegradability and, in some cases, specificity and potentially lower toxicity to the wider environment (Ahn et al. 2003). Although many effective aqueous algicidal treatments exist, few are approved for use in open marine systems, due to environmental concerns, although some have restricted use in antifouling paints and surface treatments (NOAA, 2015; Gallardo-Rodríguez et al. 2019). Several biocidal chemicals have been tested and approved for use in mariculture, for controlling shellfish and finfish pathogens or parasites (Johnston \& Santillo 2002; Read \& Fernandes 2003) and some of these may be effective in killing some HAB species.

Biological control measures include the application of microbial (viral, bacterial, fungal and/or protistan) parasites that infect $\mathrm{HABs}$ and play a significant role in the natural termination of major blooms (Brussaard 2004; Chambouvet et al. 2008; Roth et al. 2008; Jones et al. 2011; Demuez et al. 2015; Pokrzywinskia et al. 2017). Algicidal and growth inhibitory bacteria and viruses have potential for controlling HABs, due to their ability to replicate rapidly and target-specific hosts (Bibak \& Hosseini 2013; Sun et al. 2018). However, it is possible for these parasites to be too specific, rendering them unable to infect different genetic strains of HAB species, or adapt to changing environmental conditions (Sun et al. 2018; Gallardo-Rodríguez et al. 2019). Therefore, rather than using single cultured microbial species, employing a range of microbes may be more effective. Aggregates (biofilms) immobilised on substrates may be more effective in reducing $\mathrm{HAB}$ cell density by inhibiting $\mathrm{HAB}$ cell growth via nutrient uptake and allelochemical secretion, and causing cell lysis (Alex et al. 2014; Sun et al. 2018). Research is needed to quantify the release of toxins following $\mathrm{HAB}$ cell lysis and the potential for microbes to degrade them. Further research is also needed to isolate, purify and identify microbial allelochemicals/exudates and to demonstrate their efficacy for controlling different $\mathrm{HAB}$ species and genetic strains, while incurring minimal effects on non-harmful algae and other marine organisms, including cultured shellfish and finfish species (NOAA, 2015, Sun et al. 2018). Other potential biological interventions include selective breeding of shellfish with resistance to $\mathrm{HAB}$ toxins and using them as $\mathrm{HAB}$ biofilters and bioremediators (NOAA, 2015). Unquantified biosecurity risks for biological control measures currently prevent their operational use in controlling HABs at mariculture sites.

\section{Conclusions and recommendations}

Marine aquaculture (mariculture) is playing an increasingly important role in global food security. One of the most significant risks to mariculture expansion, both inshore and offshore, is the occurrence of Harmful Algal Blooms (HABs).

Global impacts from HABs on mariculture (due to finfish or shellfish mortality, poisoning of human consumers and preventative harvesting bans) currently amount to something in the region of 8 US\$ billion/year; however, $\mathrm{HAB}$ risk assessment is not a standard requirement in the planning and classification of mariculture sites. This is, in part, because HABs are natural phenomena, and because risk factors are diverse, varying greatly both spatially and temporally. For example, HABs may originate offshore, far from anthropogenic activities, and can be advected over large distances to other areas conducive for HAB development. Further research is required to guide and enable preemptive measures for mitigating $\mathrm{HAB}$ risks, including the strategic siting of mariculture infrastructure and scheduling of harvests.

Adaptive management of HAB risk, involving the prediction of HAB events and the tactical use of appropriate and approved physical, chemical and/or biological control measures, is needed as part of the sustainable development of mariculture. However, successful application requires improved understanding on the efficacy and biosafety/ specificity of the available options. There is a need also for improved understanding on the interactions among physical forcing factors (meteorological and oceanographical), and chemical (nutrient) and biological (community) factors, in order to predict where and when blooms are most likely to occur. In support of this, research should exploit the widespread occurrence of HABs, which provides opportunities for comparative assessments of $\mathrm{HAB}$ drivers around the world, including the extent to which HAB species, their population dynamics, and community interactions show similarities in responses within comparable ecosystem types. There is considerable scope to capitalise on advances in automation and (bio)sensor (DNA, RNA, protein and metabolite)-based technologies, with applications in: real-time, in situ monitoring of HAB population dynamics; defining physiological processes and underlying regulatory gene networks linked to growth and/or toxin production in $\mathrm{HAB}$ species; and building robust, mechanistic models for predicting HAB events.

Harmful algal bloom risks are generally perceived to be higher at coastal sites, which experience nutrient enrichment from agricultural runoff and municipal effluent discharges. Winds and tides can also transport and accumulate $\mathrm{HABs}$ into coastal areas, including sheltered embayments, where less turbulent and warmer waters are 
conducive for the growth of various HAB species. In these and other areas with low water exchange rates, mariculture itself can have a significant influence on HAB risk by affecting local water quality (e.g. nutrient eutrophication levels), hydrodynamics (artificial structures reducing water circulation) and plankton communities (e.g. through selective filter feeding by shellfish). More studies are required to quantify $\mathrm{HAB}$ risks against each of the above factors and their interactions and the degree to which they are influenced by different types of mariculture.

Harmful algal bloom risks associated with nutrient enrichment and eutrophication (from terrestrial sources and mariculture itself) may be mitigated by establishing mariculture sites offshore, away from the coast and/or in areas with high horizontal water exchange rates and vertical mixing. Greater understanding is required on how hydrodynamic conditions (e.g. influenced by wind, waves, tides) and bathymetry (water depth) influence dispersal versus local deposition and resuspension of nutrients and HAB propagules/cysts.

Further capacity for HAB mitigation is offered by integrated multi-trophic aquaculture (IMTA), which employs extractive bivalve shellfish and macroalgae alongside fed finfish and crustaceans, in order to recycle nutrients, thus maximising productivity and water quality simultaneously. Macroalgae (in addition to filter-feeding shellfish) can also have a direct influence on local plankton community composition and abundance - via nutrient competition, light shading and allelochemical mechanisms. Further research is required to understand how IMTA systems could be further optimised for the additional purpose of HAB attenuation, through selection of suitable, resilient finfish, shellfish and macroalgal species, and appropriate spatial deployment and stocking densities.

A key remaining question for mariculture, both inshore and offshore, is 'How will HAB risk transpire in a future warmer climate, typified by increased sea surface temperatures and water column stratification, or alternatively in a future characterised by increased atmospheric energy and more turbulent waters?' Climate change is also likely to be accompanied by HAB range extensions towards the poles. To address these issues, collaborative effort is needed that seeks to unify research themes on 'HABs, climate change and aquaculture/mariculture', as exemplified by Global$\mathrm{HAB}$, an international programme sponsored jointly by the Scientific Committee on Oceanic Research (SCOR) and the Intergovernmental Oceanographic Commission (IOC) of UNESCO.

\section{Acknowledgements}

This review was funded by the European Martime and Fisheries Fund (EMFF) grant ENG2360: Assessing and mitigating the future risks of harmful algal blooms (HABs) to wild fisheries and aquaculture. The authors have no industrial links. Brown and Lilley undertook the literature review, which was led by Brown. Expert contributions and peer reviews of manuscript drafts were provided by each of the co-authors: Lilley - marine ecology; Shutler - remote sensing, water quality and aquaculture; Lowe - microbiology; Artioli and Torres - hydrodynamic and ecosystem modelling; Berdalet - HABs; and Tyler - aquaculture. Shutler has co-authored reports by the International Ocean Colour Coordinating group (IOCCG), Berdalet is the acting chair of the GlobalHAB Scientific Steering Committee (www.globalhab.info), and this paper contributes to the implementation of the programme objectives concerning $\mathrm{HABs}$ and Aquaculture; Tyler is co-director of the Centre for Sustainable Aquaculture Futures and co-PI on RCUK's Aquaculture Research Collaborative Hub (ARCH-UK).

\section{References}

Adams C (2017) Red tide causes economic losses to Southwest Florida industry. UF/IFAS Florida Shellfish Aquaculture Featured News. January 13, 2017. URL (accessed April 2019): http://shellfish.ifas.ufl.edu/news/red-tide-causes-economiclosses-sw-florida-industry/

Adams CM, Larkin SL, Hoagland P, Sancewich B (2018) Assessing the economic consequences of harmful algal blooms: a summary of existing literature, research methods, data, and information gaps. In Shumway SE, Burkholder JM, Morton SL (eds). Harmful Algal Blooms: A Compendium Desk Reference. First Edition. Chapter 8, 696 pp. (C2018 JohnWiley \& Sons Ltd. Published 2018 by John Wiley \& Sons Ltd, Hoboken, NJ.

Ahn CY, Joung SH, Jeon JW, Kim HS, Yoon BD, Oh HM (2003) Selective control of cyanobacteria by surfactin-containing culture broth of Bacillus subtilis C1. Biotechnology Letters 25: 1137-1142.

Alex D, Mathew A, Sukumaran R (2014) Esterases immobilized on aminosilane modified magnetic nanoparticles as a catalyst for biotransformation reactions. Bioresource Technology 167: 547-550.

Aleynik D, Dale AC, Porter M, Davidson K (2016) A high resolution hydrodynamic model system suitable for novel harmful algal bloom modelling in areas of complex coastline and topography. Harmful Algae 53: 102-117.

Amin SA, Hmelo LR, van Tol HM, Durham BP, Carlson LT, Heal KR et al. (2015) Interaction and signalling between a cosmopolitan phytoplankton and associated bacteria. Nature 522: 98-101.

Andersen NG, Hansen PJ, Engell-Sørensen K, Nørremark LH, Andersen P, Lorenzen E et al. (2015) Ichthyotoxicity of the microalga Pseudochattonella farcimen under laboratory and field conditions in Danish waters. Diseases of Aquatic Organisms 116: 165-172. 
Anderson DM (2009) Approaches to monitoring, control and management of harmful algal blooms (HABs). Ocean and Coastal Management 52: 342.

Anderson DM (2012) HABs in a changing world: a perspective on harmful algal blooms, their impacts, and research and management in a dynamic era of climactic and environmental change. Harmful Algae 2012: 3-17.

Anderson DM, Kulis DM, Doucette GJ, Gallagher JC, Balech E (1994) Biogeography of toxic dinoflagellates in the genus Alexandrium from the north eastern United States and Canada. Marine Biology 120: 467-478.

Anderson DM, Glibert PM, Burkholder JM (2002) Harmful Algal Blooms and eutrophication: nutrient sources, composition, and consequences. Estuaries 25: 704-726.

Anderson DM, Burkholder JM, Cochlan WP, Glibert PM, Gobler CJ, Heil CA et al. (2008) Harmful algal blooms and eutrophication: examining linkages from selected coastal regions of the United States. Harmful Algae 8: 39-53.

Anderson DM, Cembella AD, Hallegraeff GM (2012a) Progress in understanding harmful algal blooms: paradigm shifts and new technologies for research, monitoring, and management. Annual Reviews in Marine Science 4: 143-176.

Anderson DM, Alpermann TJ, Cembella AD, Collos Y, Masseret E, Montresor M (2012b) The globally distributed genus Alexandrium: multifaceted roles in marine ecosystems and impacts on human health. Harmful Algae 14: 10-35.

Anderson CR, Berdalet E, Kudela RM, Cusack CK, Silke J, O'Rourke E et al. (2019) Scaling up from regional case studies to a global Harmful Algal Bloom observing system. Frontiers in Marine Science 6: 250. https://doi.org/10.3389/fmars.2019. 00250

Arzul G, Seguel M, Clement A (2001) Effect of marine animal excretions on differential growth of phytoplankton species. International Council for the Exploration of the Sea (ICES). Journal of Marine Science 58: 386-390.

ASIMUTH (2014) Applied simulations and Integrated modelling for the understanding of toxic and harmful algal blooms. Final Report Summary, FP7-SPACE Project ID: 261860.

Baker-Austin C, McArthur JV, Tuckfield RC, Najarro M, Lindell AH, Gooch J (2008) Antibiotic resistance in the shellfish pathogen Vibrio parahaemolyticus, isolated from the coastal water and sediment of Georgia and South Carolina, USA. Journal of Food Protection 71: 2552-2558.

Basti L, Hégaret H, Shumway SE (2018) Harmful Algal Blooms and Shellfish. In Shumway SE, Burkholder JM, Morton SL, eds. Harmful Algal Blooms a Compendium Desk Reference, pp. 135-191. John Wiley \& Sons Inc., Hoboken, NJ.

Beaulieu SE, Sengco MR, Anderson DM (2003) Using clay to control harmful algal blooms: deposition and resuspension of clay/algal flocs. Harmful Algae 4(1): 123-138.

Beketov MA, Kefford BJ, Schäfer RB, Liess M (2013) Pesticides reduce regional biodiversity of stream invertebrates. Proceedings of the National Academy of Sciences USA 110: 1103911043.
Belle SM, Nash CE (2008) Better management practices for netpen aquaculture. In: Tucker CS, Hargreaves JA (eds) Environmental Best Management Practices for Aquaculture, pp. 261330. Wiley-Blackwell, Oxford, UK.

Ben Gharbia H, Kéfi-Daly Yahia O, Cecchi P, Masseret E, Amzil Z, Herve F et al. (2017) New insights on the species-specific allelopathic interactions between macrophytes and marine HAB dinoflagellates. PLoS ONE 12: e0187963.

Berdalet E, Fleming LE, Gowen R, Davidson K, Hess P, Backer LC et al. (2016) Marine Harmful Algal Blooms, human health and wellbeing: challenges and opportunities in the 21st century. Journal of the Marine Biology Association of the United Kingdom 96 (Special Issue 01): 61.

Berdalet E, Montresor M, Reguera B, Roy S, Yamazaki H, Cembella A et al. (2017) Harmful algal blooms in fjords, coastal embayments, and stratified systems: recent progress and future research. Oceanography 30(1): 46-57.

Bibak M, Hosseini SA (2013) Review ways to control harmful algal bloom (HAB). World Journal of Fish and Marine Sciences 5: 42-44.

Boalch GT (1979) The dinoflagellate bloom on the coast of south west England, August-September 1978. Journal of the Marine Biological Association of the United Kingdom 59: 515517.

Bouwman L, Beusen A, Glibert PM, Overbeek C, Pawlowski M, Herrera J et al. (2013) Mariculture: significant and expanding cause of coastal nutrient enrichment. Environmental Research Letters 8: 044026.

Bresnan E, Davidson K, Edwards M, Fernand L, Gowen R, Hall A et al. (2013) Impacts of climate change on harmful algal blooms. MCCIP Science Review 2013: 236-243.

Brussaard CPD (2004) Viral control of phytoplankton populations - a review. Journal of Eukaryotic Microbiology 51: 125138.

Buck BH, Troell MF, Krause G, Angel DL, Grote B, Chopin T (2018) State of the art and challenges for offshore integrated multi-trophic aquaculture (IMTA). Frontiers in Marine Science 5: 165.

Burkholder JM (1998) Implications of harmful microalgae and heterotrophic dinoflagellates in management of sustainable marine fisheries. Ecological Appllication 8: S37-S62.

Butenschön M, Clark J, Aldridge JN, Allen JI, Artioli Y, Blackford J et al. (2016) ERSEM 15.06: a generic model for marine biogeochemistry and the ecosystem dynamics of the lower trophic levels. Geoscience Model Development 9: 1293-1339.

Calbet A (2008) The trophic roles of microzooplankton in marine systems. ICES Journal of Marine Science 65: 325-331.

California Ocean Science Trust (2016). Framing the science around harmful algal blooms and California fisheries: Scientific insights, recommendations and guidance for California. 2016. California Ocean Science Trust, Oakland, CA. (accessed November 2019) Available from URL : https:/fisheries.legis lature.ca.gov/sites/fisheries.legislature.ca.gov/files/u8/2016-10$25 \% 20$ HABs $\% 20$ and $\% 20$ CA $\% 20$ Fisheries $\% 20$ Science $\%$ 20Guidance.pdf 
Callaway R, Shinn AP, Grenfell SE, Bron JE, Burnell G, Cook EJ et al. (2012) Review of climate change impacts on marine aquaculture in the UK and Ireland. Aquatic Conservation: Marine and Freshwater Ecosystems 22: 389-421.

Campbell DA, Kelly MS, Busman M, Wiggins E, Fernandes TF (2003) Impact of preparation method on gonad domoic acid levels in the scallop, Pecten maximus (L.). Harmful Algae 2: 215-222.

Campbell L, Henrichs DW, Olson RJ, Sosik HM (2013) Continuous automated imaging-in-flow cytometry for detection and early warning of Karenia brevis blooms in the Gulf of Mexico. Environmental Science and Pollution Research 20: 6896-6902.

Castberg T, Torgersen T, Aasen J, Aune T, Naustvoll L-J (2004) Diarrhoetic shellfish poisoning toxins in Cancer pagurus Linnaeus, 1758 (Brachyura, Canceridae) in Norwegian waters. Sarsia 89: 311-317.

Chambouvet A, Morin P, Marie D, Guillou L (2008) Control of toxic marine dinoflagellate blooms by serial parasitic killers. Science 322: 1254-1257.

Chopin T, Cooper JA, Reid G, Cross S, Moore C (2012) Open-water integrated multi-trophic aquaculture: environmental biomitigation and economic diversification of fed aquaculture by extractive aquaculture. Reviews in Aquaculture 4: 209-220.

Clément A, Lincoqueo L, Saldivia M, Brito CG, Muñoz F, Fernández C et al. (2016) Exceptional summer conditions and HABs of Pseudochattonella in Southern Chile create record impacts on salmon farms. Harmful Algae News 53: 1-3.

Cochlan WP, Trainer VL, Trick CG, Wells ML, Bill BD, Eberhart B-TL (2012). Heterosigma akashiwo in the Salish Sea: defining growth and toxicity leading to fish kills. In: Kim HG, Reguera B, Hallegraeff G, Lee CK , Han MS, Choi JK (eds), Harmful Algae 2012. 15th International Conference on Harmful Algae, pp. 203-206. International Society for the study of harmful algae, Changwon, Gyeongnam, Korea.

CTA (2013) Fish-farming: the new driver of the blue economy, Briefing n. 32. Technical Centre for Agricultural and Rural Cooperation ACP-EU (CTA). URL (accessed 25 January 2019): https://europa.eu/capacity4dev/file/15656/download?to ken=J7_MU3_d

Cuellar-Martinez T, Ruiz-Fernández AC, Alonso-Hernández C, Amaya-Monterrosa O, Quintanilla R, Carrillo-Ovalle HL et al. (2018) Addressing the Problem of Harmful Algal Blooms in Latin America and the Caribbean- A Regional Network for Early Warning and Response. Frontiers in Marine Science 5: 409.

Cusack C, Dabrowski T, Lyons K, Berry A, Westbrook G, Salas R et al. (2016) Harmful algal bloom forecast system for SW Ireland. Part II: are operational oceanographic models useful in a HAB warning system. Harmful Algae 53: 86-101.

Dabrowski T, Lyons K, Nolan G, Berry A, Cusack C, Silke J (2016) Bloom forecast system for SW Ireland. Part I: description and validation of an operational forecasting model. Harmful Algae 53: 64-76.
Davidson K (2014) The challenges of incorporating realistic simulations of marine protists in biogeochemically based mathematical models. Acta Protozoologica 53(1): 129-138.

Davidson K, Miller PI, Wilding TA, Shutler J, Bresnan E, Kennington $\mathrm{K}$ et al. (2009) A large and prolonged bloom of Karenia mikimotoi in Scottish waters in 2006. Harmful Algae 8: 349-361.

Davidson K, Gowen RJ, Tett P, Bresnan E, Harrison PJ, McKinney A et al. (2012) Harmful algal blooms: how strong is the evidence that nutrient ratios and forms influence their occurrence? Estuarine, Coastal and Shelf Science 115: 399e413.

Davidson K, Gowen RJ, Harrison PJ, Fleming LE, Hoagland P (2014) Anthropogenic nutrients and harmful algae in coastal waters. Journal of Environmental Management 146: 206-216.

Davidson K, Baker C, Higgins C, Higman W, Swan S, Veszelovszki A et al. (2015) Potential threats posed by new or emerging marine biotoxins in UK waters and examination of detection methodologies used for their control: cyclic imines. Marine Drugs 13: 7087-7112.

Davidson K, Anderson DM, Mateus M, Reguera B, Silke J, Sourisseau M et al. (2016) Forecasting the risk of harmful algal blooms. Harmful Algae 53: 1-7.

De Silva SS, Soto D (2009) Climate change and aquaculture: potential impacts, adaptation and mitigation. In: Cochrane $\mathrm{K}$, De Young C, Soto D, Bahri T (eds). FAO Fisheries and Aquaculture Technical Paper No. 530. FAO, Rome, Italy. Accessed 25 Aug 2019: http://www.fao.org/3/i0994e/i0994e00.htm

Dempster T, Sanchez-Jerez P, Bayle-Sempere JT, Kingsford M (2004) Extensive aggregations of wild fish at coastal sea-cage fish farms. Hydrobiologia 525: 245-248.

Demuez M, González-Fernández C, Ballesteros M (2015) Algicidal microorganisms and secreted algicides: new tools to induce microalgal cell disruption. Biotechnology Advances 33 (8): 1615.

Dias PJ, Munoz J, Huisman JM, McDonald JI (2015) Biosecurity monitoring of Harmful Algal Bloom (HAB) species in Western Australian waters: first confirmed record of Alexandrium catenella (Dinophyceae). BioInvasions Records 4: 233-241.

Diaz RJ, Rosenberg R (2008) Spreading dead zones and consequences for marine ecosystems. Science 321: 926-929.

Díaz PA, Ruiz-Villarreal M, Pazos Y, Moita T, Reguera B (2016) Climate variability and Dinophysis acuta blooms in an upwelling system. Harmful Algae 53: 145-159.

Dickey TD (2001) The role of new technology in advancing ocean biogeochemical research. Oceanography 14: 108-120.

Drumm A (2010) Evaluation of the Promotion of Offshore Aquaculture Through a Technology Platform (OATP). Marine Institute, Galway, Ireland. pp. 46URL (accessed 28 August 2019): www.offshoreaqua.com/docs/OATP_Final_Publishable_ report.pdf

Directive 2006/113/EC of the European Parliament and of the Council of 12 December 2006 on the quality required of shellfish watershttp://data.europa.eu/eli/dir/2006/113/oj

Directive 2000/60/EC of the European Parliament and of the Council of 23 October 2000 establishing a framework for 
Community action in the field of water policy. http://data.eu ropa.eu/eli/dir/2000/60/oj

Eckford-Soper LK, Bresnan E, Lacaze J-P, Green DH, Keith Davidson K (2016) The competitive dynamics of toxic Alexandrium fundyense and non-toxic Alexandrium tamarense: The role of temperature. Harmful Algae 53: 135-144.

El-Habashi A, Duran CM, Lovko V, Tomlinson MC, Stumpf RP, Ahmed S (2017) Satellite retrievals of Karenia brevis harmful algal blooms in the West Florida shelf using neural networks and impacts of temporal variabilities. Journal of Applied Remote Sensing 11: 032408.

Eong YS, Sulit VT (2015) Monitoring and identification of Harmful Algal Blooms in Southeast Asia to support SDG 14.1. Fish for the People, Magazine of the Southeast Asian Fisheries Development Centre 15: 39-46.

Espinosa EP, Perrigault M, Ward JE, Shumway SE, Allam B (2009) Implication of lectins associated with feeding organs in particle selection in the oyster Crassostrea virginica. Biological Bulletin 217: 130-141.

Estrada M, Berdalet E (1997) Phytoplankton in a turbulent world. In: Marrasé C, Saiz E, Redondo JM (eds), Lectures on Plankton and Turbulence. Scientia Marina 61: 125-140

Fang J, Zhang J, Xiao T, Huang D, Liu S (2016) Integrated multi-trophic aquaculture (IMTA) in Sanggou Bay, China. Aquaculture Environment Interactions 8: 201-205.

FAO (2012) The State of the World Fisheries and Aquaculture 2012. FAO Fisheries and Aquaculture Department, FAO. URL (accessed 25 August 2019): http://www.fao.org/docrep/016/ i2727e/i2727e.pdf

FAO (2015) FAO Global Aquaculture Production Statistics Database Updated to 2013: Summary Information. Food and Agriculture Organization of the United Nations, Rome, Italy. URL (accessed 25 August 2019): http://www.fao.org/3/a-i4899e.pdf

FAO (2018) The State of World Fisheries and Aquaculture 2018: Meeting the Sustainable Development Goals. 200 pp. Food and Agriculture Organization of the United Nations (UN FAO), Rome, Italy. URL (accessed 25 August 2019): http://www.fao. org/3/i9540en/I9540EN.pdf

FAO, IFAD, UNICEF, WFP and WHO (2018) The State of Food Security and Nutrition in the World 2018. Building climate resilience for food security and nutrition. UN Food and Agriculture Organisation, Rome, Italy. URL (accessed 25 August 2019): http://www.fao.org/3/i9553en/i9553en.pdf

Farrell H, Gentien P, Fernand L, Lunven M, Reguera B, González-Gil S et al. (2012) Scales characterising a high density thin layer of Dinophysis acuta Ehrenberg and its transport within a coastal jet. Harmful Algae 15: 36-46.

Fehling J, Green DH, Davidson K, Bolch CJ, Bates SB (2004) Domoic acid production by Pseudo-nitzschia seriata (Bacillariophyceae) in Scottish waters. Journal of Phycology 40: 622630.

Ferreira JG, Sequeira A, Hawkins AJS, Newton A, Nickell T, Pastres R et al. (2009) Analysis of coastal and offshore aquaculture: application of the FARM model to multiple systems and shellfish species. Aquaculture 292: 129-138.
Ferreira JG, Saurel C, Lencart E, Silva JD, Nunes JP, Vazquez F (2014) Modelling of interactions between inshore and offshore aquaculture. Aquaculture 426-427: 154-164.

Flaherty KE, Landsberg JH (2011) Effects of a persistent red tide (Karenia brevis) bloom on community structure and speciesspecific relative abundance of nekton in a Gulf of Mexico estuary. Estuaries and Coasts 34(2): 417-439.

Flynn KJ, McGillicuddy DJ Jr (2018) Modeling marine Harmful Algal Blooms: current status and future prospects. In: Shumway SE, Burkholder JM, Morton SL (eds) Harmful Algal Blooms a Compendium Desk Reference, pp. 115-134. John Wiley \& Sons Inc., Hoboken, NJ.

Food and Agriculture Organisation of the United Nations (FAO) (2012) The State of World Fisheries and Aquaculture 2012. Food and Agriculture Organisation of the United Nations, Rome, Italy. URL (accessed 25 August 2019): www.fa o.org/docrep/016/i2727e/i2727e00.htm

Franklin DJ, Brussaard CPD, Berges JA (2006) What is the role and nature of programmed cell death in phytoplankton ecology? European Journal of Phycology 41(1): 1-14.

Friedman MA, Fernandez M, Backer LC, Dickey RW, Bernstein J, Schrank K et al. (2017) An updated review of ciguatera fish poisoning: clinical, epidemiological, environmental, and public health management. Marine Drugs 15: E72.

Froehlich HE, Gentry RR, Halpern BS (2016) Synthesis and comparative analysis of physiological tolerance and life-history growth traits of marine aquaculture species. Aquaculture 460: 75-82.

Froehlich HE, Smith A, Gentry RR, Halpern BS (2017) Offshore Aquaculture: I Know It When I See It. Frontiers in Marine Science 4: 154.

Fukuyo Y, Imai I, Kodama M, Tamai K (2002) Red tides and other harmful algal blooms in Japan. In: Taylor FJR, Trainer VL (eds), Harmful Algal Blooms in the PICES Region of the North Pacific. PICES Report No. 23, pp.7-20. North Pacific Marine Science Organization (PICES), Sidney, Canada.

Furey A, O'Doherty S, O'Callaghan K, Lehane M, James KJ (2010) Azaspiracid poisoning (AZP) toxins in shellfish: toxicological and health considerations. Toxicon 56(2): 173190.

Gachon CMM, Sime-Ngando T, Strittmatter M, Chambouvet A, Kim GH (2010) Algal diseases: spotlight on a black box. Trends in Plant Science 15: 633-640.

Gallardo-Rodríguez JJ, Astuya-Villalón A, Llanos-Rivera A, Avello-Fontalba V, Ulloa-Jofré V (2019) A critical review on control methods for harmful algal blooms. Reviews in Aquaculture 2019: 661-684.

Gentien P, Lunven M, Lazure P, Youenou A, Crassous MP (2007) Motility and autotoxicity in Karenia mikimotoi (Dinophyceae). Philosophical Transactions of the Royal Society London B 362: 1937-1946.

Gentry RR, Lester SE, Kappel CV, White C, Bell TW, Stevens J et al. (2016) Offshore aquaculture: spatial planning principles for sustainable development. Ecology and Evolution 7(2): 733743. 
Gentry RR, Froehlich HE, Grimm D, Kareiva P, Parke M, Rust $M$ (2017) Mapping the global potential for marine aquaculture. Nature Ecology and Evolution 1: 1317-1324.

GESAMP (2001) Group of Experts on the Scientific Aspects of Marine Pollution (GESAMP) Reports and Studies. United Nations Environment Programme, Nairobi: 2001. Global Environment Outlook 3, EARTH SCAN, Past, present and future perspectives. Protecting the oceans from land-based activities. Land-based sources and activities affecting the quality and uses of the marine, coastal and associated freshwater environment. No. 71.11 .

Gibbs MT (2004) Interactions between bivalve shellfish farms and fishery resources. Aquaculture 240: 267-296.

Gillibrand PA, Siemering B, Miller PI, Davidson K (2016) Individual-based modelling of the development and transport of a Karenia mikimotoi bloom on the North-west European continental shelf. Harmful Algae 53: 118-134.

Gilliom RJ (2007) Pesticides in the U.S. streams and groundwater. Environmental Science and Technology 41: 3408-3414.

Glibert PM, Anderson DM, Gentien P, Granéli E, Sellner KG (2005) The global, complex phenomena of harmful algal blooms. Oceanography 18(2): 136-147.

Glibert PM, Maranger R, Sobota DJ, Bouwman L (2014a) The Haber Bosch-harmful algal bloom (HB-HAB) link. Environmental Research Letters 9: 105001.

Glibert PM, Allen IJ, Artioli Y, Beusen A, Bouwman L, Harle J et al. (2014b) Vulnerability of coastal ecosystems to changes in harmful algal bloom distribution in response to climate change: projections based on model analysis. Global Change Biology 20: 3845-3858.

GlobalHAB (2017). Global Harmful Algal Blooms, Science and Implementation Plan. E Berdalet et al. (eds.). SCOR and IOC, Delaware and Paris, 64pp. http://www.globalhab.info/science/ globalhab-new-topic/habs-and-aquaculture

Gobler CJ, Berry DL, Dyhrman ST, Wilhelm SW, Salamov A, Lobanov AV et al. (2011) Niche of harmful alga Aureococcus anophagefferens revealed through ecogenomics. Proceedings of the National Academy of Sciences USA 108: 4352-4357.

Gobler CJ, Doherty OM, Hattenrath-Lehmann TK, Griffith AW, Kang Y, Litaker RW (2017) Ocean warming since 1982 has expanded the niche of toxic algal blooms in the North Atlantic and North Pacific oceans. Proceedings of the National Academy of Sciences USA 114: 4975-4980.

Gowen RJ, Tett P, Bresnan E, Davidson K, McKinney A, Milligan $S$ et al. (2012) Anthropogenic nutrient enrichment and blooms of harmful micro-algae. Oceanography and Marine Biology 50: 65-126.

Grant J, Curran KJ, Guyondet TL, Tita G, Bacher C, Koutitonsky $\mathrm{V}$ et al. (2007) A box model of carrying capacity for suspended mussel aquaculture in Lagune de la Grande-Entrée, Iles-de-laMadeleine, Québec. Ecological Modelling 200: 193-206.

Hallegraeff GM (1993) A review of harmful algal blooms and their apparent global increase. Phycologia 32(2): 79-99.

Hallegraeff GM (2003) Harmful algal blooms: a global overview. In: Hallegraeff GM, Anderson DM, Cembella AD (eds)
Manual on Harmful Marine Microalgae, pp. 25-49. UNESCO Publishing, Paris, France.

Hallegraeff GM, Bolch CJ (1991) Transport of toxic dinoflagellate cysts via ships' ballast water. Marine Pollution Bulletin 22: 27-30.

Hallegraeff GM, Bolch CJ (1992) Transport of diatom and dinoflagellate resting spores in ships' ballast water: implications for plankton biogeography and aquaculture. Journal of Plankton Research 14: 1067-1084.

Hallegraeff G, Bresnan E, Enevoldsen H, Schweibold L, Zingone A (2017) Call to contribute to global harmful algal bloom status reporting. Harmful Algae News 58: 1-3.

Harris TD, Smith VH (2015) Do persistent organic pollutants stimulate cyanobacterial blooms? Inland Waters 6: 124-130.

Hedberg N, Kautsky N, Kumblad L, Wikström SA (2018) Limitations of Using Blue Mussel Farms as a Nutrient Reduction Measure in the Baltic Sea. Report 2/2018, Baltic Sea Centre, Stockholm University. URL (accessed 10 Jan 2019): https:// www.su.se/polopoly_fs/1.406424.1539853328!/menu/standa rd/file/BSC_Mussels_report_2_2018_lowres.pdf

Hégaret H, Wikfors GH, Shumway SE (2007) Diverse feeding responses of five species of bivalve mollusc when exposed to three species of harmful algae. Journal of Shellfish Research 26: 549-559.

Hégaret H, Shumway SE, Wikfors GH, Pate S, Burkholder JM (2008) Potential transport of harmful algae via relocation of bivalve molluscs. Marine Ecology Progress Series 361: 169-179.

Heisler J, Gilbert P, Burkholder J, Anderson D, Cochlan W, Dennison W et al. (2008) Eutrophication and harmful algal blooms: a scientific consensus. Harmful Algae 8: 3-13.

Higman WA, Turner A, Baker C, Higgins C, Veszelovszki A, Davidson K (2014) Research to support the development of a monitoring programme for new or emerging marine biotoxins in shellfish in UK Waters. Food Standards Agency report FS513005, March 2014.o

Hinder SL, Hays GC, Brooks CJ, Davies AP, Edwards M, Walne AW et al. (2011) Toxic marine microalgae and shellfish poisoning in the British Isles: history, review of epidemiology, and future implications. Environ Health 10: 54.

Hoagland P, Scatasta S (2006) The Economic Effects of Harmful Algal Blooms. In: Granéli E, Turner JT (eds) Ecology of Harmful Algae. Ecological Studies (Analysis and Synthesis), pp. 391402. Springer, Berlin, Heidelberg.

Hoagland P, Anderson DM, Kaoru Y, White AW (2002) The economic effects of harmful algal blooms in the United States: estimates, assessment issues, and information needs. Estuaries 25: 677-695.

Holdt SL, Edwards MD (2014) Cost-effective IMTA: a comparison of the production efficiencies of mussels and seaweed. Journal of Applied Phycology 26: 933-945.

Huston MA, Wolverton S (2009) The global distribution of net primary production: resolving the paradox. Ecological Monographs 79: 343-377.

Inaba N, Trainer VL, Nagain S, Kojima S, Sakami T, Takagi S et al. (2019) Dynamics of seagrass bed microbial communities 
used to control artificial Chattonella blooms: a microcosm study. Harmful Algae 84: 139-150.

International Ocean-Colour Coordinating Group (IOCCG) (2009) Remote Sensing Applications in Marine Aquaculture. Forget M-H, Stuart V, Platt T (eds.), Reports of the International Ocean-Colour Coordinating Group, No. 8, pp. 77-87. IOCCG, Dartmouth, Canada.

International Ocean-Colour Coordinating Group (IOCCG) (2014) Detection of Dominant Algal Blooms by Remote Sensing. Sathyendranath S (ed.), Reports of the International Ocean-Colour Coordinating Group, No. 15, pp. 39-68. IOCCG, Dartmouth, Canada.

Jacobson DM, Andersen RA (1994) The discovery of mixotrophy in photosynthetic species of Dinophysis (Dinophyceae): light and electron microscopical observations of food vacuoles in Dinophysis acuminata, D. norvegica and two heterotrophic dinophysoid dinoflagellates. Phycologia 33(2): 97-110.

James KJ, Carey B, O’Halloran J, Van Pelt FNAM, Krabakova ZS (2010) Shellfish toxicity: human health implications of marine algal toxins. Epidemiology and Infection 138: 927-940.

Jenkinson IR, Connors PP (1980) The occurrence of the red tide organism, Gyrodinium aureolum Hulbert (Dinophyceae), round the south and west of Ireland in August and September, 1979. Journal Sherkin Island 1: 127-146.

Johnston P, Santillo D (2002) Chemical Usage in Aquaculture: Implications for Residues in Market Products. Greenpeace Research Laboratories Technical Note 06/2002, Department of Biological Sciences, University of Exeter, Exeter, UK.

Jones KJ, Ayres P, Bullock AM, Roberts RJ, Tett P (1982) A red tide of Gyrodinium aureolum in sea lochs of the firth of Clyde and associated mortality of pond-reared salmon. Journal of the Marine Biological Association UK 62: 771-782.

Jones KL, Mikulski CM, Barnhorst A, Doucette GJ (2011) Comparative analysis of bacterioplankton assemblages from Karenia brevis bloom and non-bloom water on the west Florida shelf (Gulf of Mexico, USA) using16S rRNA gene clone libraries. FEMS Microbiology Ecology 73: 468-485.

Kapetsky JM, Aguilar-Manjarrez J, Jenness J (2013) A Global Assessment of Potential for Offshore Mariculture Development From a Spatial Perspective, 181 pp. FAO Fisheries and Aquaculture Technical Paper. No. 549. FAO, Rome, Italy.

Kim HG (2006) Mitigation and controls of HABs. In Granéli E, Turner JT (eds), Ecology of Harmful Algae. Ecological Studies, Vol. 189, pp. 327-338, Springer-Verlag, Berlin, Germany.

Kirkpatrick B, Fleming LE, Squicciarini D, Backer LC, Clark R, Abraham W et al. (2004) Literature review of Florida red tide: implications for human health effects. Harmful Algae 3: 99 115.

Kong F, Yu R, Zhang Q (2012) Primary analyses on the causative species of a bloom in the Sanggou Bay. Marine Environmental Science 31: 824-829.

Krimsky L, Staugler B, Hall-Scharf B, Stump K, Burton R (2018) Understanding Florida's Red Tide. SeaGrant/University of Florida/IFAS Blog URL (accessed April 2019): https://www.f lseagrant.org/news/2018/12/understanding-floridas-red-tide/
Kudela RM, Seeyave S, Cochlan WP (2010) The role of nutrients in regulation and promotion of harmful algal blooms in upwelling systems. Progress in Oceanography 85(1-2): 122135.

Kudela RM, Bickel A, Carter ML, Howard MDA, Rosenfeld L (2015). The monitoring of harmful algal blooms through ocean observing: the development of the California Harmful Algal Bloom Monitoring and Alert Program in Coastal Ocean Observing Systems. In: Liu Y, Kerkering H, Weisberg RH (eds.), Coastal Ocean Observing Systems. pp. 58-75. Academic Press, New York, NY.

Kurekin A, Miller PI, Van der Woerd HJ (2014) Satellite discrimination of Karenia mikimotoi and Phaeocystis harmful algal blooms in European coastal waters: merged classification of ocean colour data. Harmful Algae 31: 163-176.

Lafferty KD, Harvell CD, Conrad JM, Friedman CS, Kent ML, Kuris AM et al. (2015) Infectious diseases affect marine fisheries and aquaculture economics. Annual Reviews in Marine Science 7: 471-496.

Landsberg JH (2002) The effects of Harmful Algal Blooms on aquatic organisms. Reviews in Fisheries Science 10(2): 113390.

Landsberg JH, Flewelling LJ, Naar J (2009) Karenia brevis red tides, brevetoxins in the food web, and impacts on natural resources: decadal advancements. Harmful Algae 8: 598-607.

Le Gouvello R et al. (2017) Aquaculture and marine protected areas: potential opportunities and synergies. Aquatic Conservation: Marine and Freshwater Ecosystems 27(S1): 138-150.

Leadbetter A, Silke J, Cusack C (2018) Creating a Weekly Harmful Algal Bloom Bulletin. Marine Institute, Galway, Ireland, 63pp. http://hdl.handle.net/10793/1344

Lee KH, Jeong HJ, Kwon JE, Kang HC, Kim JH, Jang SH et al. (2016) Mixotrophic ability of the phototrophic dinoflagellates Alexandrium andersonii, A. affine, and A. fraterculus. Harmful Algae 59: 67-81.

Lefebvre KA, Tilton SC, Bammler TK, Beyer RP, Srinouanprachan S, Stapleton PL et al. (2007) Gene expression profiles in zebrafish brain after acute exposure to domoic acid at symptomatic and asymptomatic doses. Toxicology Science 107 (1): 65-77.

Lenes JM, Walsh JJ, Darrow BP (2013) Simulating cell death in the termination of Karenia brevis blooms: implications for predicting aerosol toxicity vectors to humans. Marine Ecology Progress Series 493: 71-81.

Li SC, Wang WX, Hsieh DP (2002) Effects of toxic dinoflagellate Alexandrium tamarense on the energy budgets and growth of two marine bivalves. Marine Environmental Research 53(2): 145-160.

Li J, Glibert PM, ZhouMJ LuSH, Lu DD (2009) Relationships between nitrogen and phosphorus forms and ratios and the development of dinoflagellate blooms in the East China Sea. Marine Ecology Progress Series 383: 11-26.

Lin J, Li C, Zhang S (2016) hydrodynamic effect of a large offshore mussel suspended aquaculture farm. Aquaculture 451: $147-155$. 
Lin C-H, Flynn KJ, Mitra A, Glibert PM (2018) Simulating effects of variable stoichiometry and temperature on mixotrophy in the harmful dinoflagellate Karlodinium veneficum. Frontiers in Marine Science 5: 320. doi.org/10.3389/ fmars.2018.00320.

Liu H, Su J (2017) Vulnerability of China's nearshore ecosystems under intensive mariculture development. Environmental Science and Pollution Research 24: 8957-8966.

Loureiro S, Jauzein C, Garcés E, Collos Y, Camp J, Vaqué D (2008) The significance of organic nutrients in the nutrition of Pseudo-nitzschia delicatissima (Bacillariophyceae). Journal of Plankton Research 31: 399-410.

Lovatelli A, Aguilar-Manjarrez J, Soto D (2013) Expanding Mariculture Further Offshore: Technical, Environmental, Spatial and Governance Challenges. FAO Technical Workshop. 22-25 March 2010. Orbetello, Italy. FAO Fisheries and Aquaculture Proceedings No. 24. FAO, Rome, Italy.

Lu D, Qi Y, Gu H, Dai X, Wang H, Gao Y et al. (2014) Causative species of harmful algal blooms in Chinese coastal waters. Algological Studies 145: 145-168.

Lucas LV, Cloern JE, Thompson JK, Stacey MT, Koseff JR (2016) Bivalve grazing can shape phytoplankton communities. Frontiers in Marine Science 3: 14. https://doi.org/10.3389/ fmars.2016.00014

Lundholm NL, Skoy J, Pocklington R, Moestrup O (1994) Domoic acid, the toxic amino acid responsible for amnesic shellfish poisoning, now in Pseudonitzschia seriata (Bacillariophyceae) in Europe. Phycologia 33: 475-478.

Maguire J, Cusack C, Ruiz-Villarreal M, Silke J, McElligot D, Davidson K (2016) Applied simulations and integrated modelling for the understanding of toxic and harmful algal blooms (ASIMUTH): integrated HAB forecast systems for Europe's Atlantic Arc. Harmful Algae 53: 160-166.

Manfrin C, De Moro G, Torboli V, Venier P, Pallavicini A, Gerdol M (2012) Physiological and molecular responses of bivalves to toxic dinoflagellates. Invertebrate Survival Journal 9: 184-199.

McGillicuddy DJ Jr, Anderson DM, Lynch DR, Townsend DW (2005) Mechanisms regulating large-scale seasonal fluctuations in Alexandrium fundyense populations in the Gulf of Maine: results from a physical-biological model. Deep Sea Research Part II: Topical Studies in Oceanography 52: 26982714.

Mitchell S, Rodgers H (2007) Pathology of wild and cultured fish affected by a Karenia mikimotoi bloom in Ireland, 2005. Bulletin-European Association of Fish Pathologists 27 (1): 3942.

Modica A, Scilipoti D, La Torre R, Manganaro A, Sara G (2006) The effect of mariculture facilities on biochemical features of suspended organic matter (southern Tyrrhenian, Mediterranean). Estuarine Coastal and Shelf Science 66: 177-184.

Montagnes DJS, Chambouvet A, Guillou L, Fenton A (2008) Responsibility of microzooplankton and parasite pressure for the demise of toxic dinoflagellate blooms. Aquatic Microbial Ecology 53: 211-225.
Munday R (2013) Is protein phosphatase inhibition responsible for the toxic effects of okadaic acid in animals? Toxins (Basel) 5(2): 267-285.

National Oceanic and Atmospheric Administration (NOAA) (2016) Fisheries of the Caribbean, Gulf, and South Atlantic; Aquaculture. National Marine Fisheries Service (NMFS); National Oceanic and Atmospheric Administration (NOAA); Department of Commerce, Washington, DC.

Nayar S, Bott K (2014) Current status of global cultivated seaweed production and markets. World Aquaculture 45(2): 3237.

Newell RIE (2004) Ecosystem influences of natural and cultivated populations of suspension-feeding bivalve molluscs: a review. Journal of Shellfish Research 23(1): 51-61.

Nishitani L, Erickson G, Chew KK (1985) Role of the parasitic dinoflagellate Amoebophrya ceratii in control of Gonyaulax catenella populations. In: Andersen DM, White AW, Baden DG (eds), Toxic Dinoflagellates, pp. 225-230. Elsevier, New York, NY.

NOAA (2015) Programmatic Environmental Assessment for the prevention, control, and mitigation of Harmful Algal Blooms Program. URL (accessed April 2019): https://cdn.coastalscie nce.noaa.gov/page-attachments/about/pcm_hab_pea_finaldoc. pdf

NOAA National Oceanic and Atmospheric Administration (2004) Action Plan for Harmful Algal Blooms and the Gulf of Mexico Coastal Ocean Observing System: Results from a Regional Workshop. NOAA Coastal Services Center. NOAA/ CSC/20516-PUB. 27 p.

Okaichi T (1989) Red tide problems in the Seto Inland Sea, Japan. In: Okaichi T, Anderson DM, Nemoto T (eds) Red Tides, Biology, Environmental Science and Toxicology, pp. 137142. Elsevier, New York, NY.

Paerl HW, Hall NS, Peierls BL, Rossignol KL (2014) Evolving paradigms and challenges in estuarine and coastal eutrophication dynamics in a culturally and climatically stressed world. Estuaries and Coasts 37(2): 243-258.

Park TG, Lim WA, Park YT, Lee CK, Jeong HJ (2013) Economic impact, management and mitigation of red tides in Korea. Harmful Algae 30: S131-S143.

Pastres R, Borga F, Brigolin D, Galparsoro I, Tett P (2018) Guide to the AquaSpace ToolBox AquaSpace: Ecosystem Approach to making Space for Aquaculture. EU Horizon 2020 project grant $\mathrm{n}^{\circ} .633476 .13 \mathrm{pp}$.

Paterson R, Mcneill S, Mitchell E, Adams T, Swan S, Clarke D et al. (2017) Environmental control of harmful dinoflagellates and diatoms in a fjordic system. Harmful Algae 69: $1-17$.

Peperzak L, Poelman M (2008) Mass mussel mortality in The Netherlands after a bloom of Phaeocystis globosa (prymnesiophyceae). Journal of Sea Research 60: 220-222.

Peters F, Arin L, Marrasé C, Berdalet E, Sala MM (2006) Effects of small-scale turbulence on the growth of two diatoms of different size in a phosphorus-limited medium. Journal of Marine Systems 61: 134-148. 
Petersen JK, Hansen JW, Laursen MB, Clausen P, Carstensen J, Conley DJ (2008) Regime shift in a coastal marine ecosystem. Ecological Applications 18: 497-510.

Petersen JK, Hasler B, Timmermann K, Nielsen P, Tørring DB, Larsen MM et al. (2014) Mussels as a tool for mitigation of nutrients in the marine environment. Marine Pollution Bulletin 82(1-2): 137-143.

Pickett ML (2018) Toxic 'red tide' algae bloom is killing Florida wildlife and menacing tourism. Guardian newspaper Tue 14 Aug 2018. URL (accessed 14 January 2019): https://www.the guardian.com/us-news/2018/aug/13/florida-gulf-coast-redtide-toxic-algae-bloom-killing-florida-wildlife

Pierce RH, Henry MS, Higham CJ, Blum P, Sengco MR, Anderson DM (2004) Removal of harmful algal cells (Karenia brevis) and toxin from seawater culture by clay flocculation. Harmful Algae 3: 141-148.

Pitcher GC, Calder D (2000) Harmful algal blooms of the southern Benguela Current: a review and appraisal of monitoring from 1989 to 1997. South African Journal of Marine Science 22: 255-271.

Pitcher GC, Jiménez AB, Kudela RM, Reguera B (2017) Harmful algal blooms in eastern boundary upwelling systems: a GEOHAB Core Research Project. Oceanography 30(1): 22-35.

Pitta P, Apostolaki ET, Giannoulaki M, Karakassis I (2005) Mesoscale changes in the water column in response to fish farming zones in three coastal areas in the Eastern Mediterranean Sea. Estuarine, Coastal and Shelf Science 65: 501-512.

Pokrzywinskia KL, Tilney CL, Modla S, Caplan JL, Ross J, Warner ME et al. (2017) Effects of the bacterial algicide IRI160AA on cellular morphology of harmful dinoflagellates. Harmful Algae 62: 127-135.

Rabalais NN, Diaz RJ, Levin LA, Turner RE, Gilbert D, Zhang J (2010) Dynamics and distribution of natural and humancaused hypoxia. Biogeosciences 7(2): 585-619.

Raine R, O'Boyle S, O'Higgins T, White M, Patching J, Cahill B et al. (2001) A satellite and field portrait of a Karenia mikimotoi bloom off the south coast of Ireland, August 1998. Hydrobiologia 465: 187-193.

Raine R, Edwards M, Reid PC, Bresnan E, Fernand L (2008) Harmful Algal Blooms in Marine Climate Change Impacts Annual Report Card 2007-2008. In: Baxter JM, Buckley PJ, Wallace CJ (eds.), Scientific Review, 8pp. URL (accessed 26 August 2019): www.mccip.org.uk/arc/2007/PDF/HABs.pdf

Ramanan R, Kim B-H, Cho D-H, Oh HM, Kim H-S (2016) Algae-bacteria interactions: evolution, ecology and emerging applications. Biotechnology Advances 34(1): 14-29.

Ramsdell JS, Zabka TS (2008) In utero DA toxicity: a fetal basis to adult disease in the California sea lion (Zalophus californianus). Marine Drugs 6(2): 262-290.

Read P, Fernandes T (2003) Management of environmental impacts of marine aquaculture in Europe. Aquaculture 226: 139-163.

Reguera B, Riobó P, Rodríguez F, Díaz PA, Pizarro G, Paz B et al. (2014) Dinophysis Toxins: causative Organisms, Distribution and Fate in Shellfish. Marine Drugs 12(1): 396-461.
Relyea RA (2009) A cocktail of contaminants: how mixtures of pesticides at low concentrations affect aquatic communities. Oecologia 159: 363-376.

Rengefors K, Karlsson I, Hansson L-A (1998) Algal cyst dormancy: a temporal escape from herbivory. Proceedings of the Royal Society B: Biological Sciences 265: 1353-1358.

Robineau B, Gagne JA, Fortier L, Cembella AD (1991) Potential impact of a toxic dinoflagellate (Alexandrium excavatum) bloom on survival of fish and crustacean larvae. Marine Biology 108: 293-301.

Roelke D, Buyukates Y (2001) The diversity of harmful algal bloom-triggering mechanisms and the complexity of bloom initiation. Human and Ecological Risk Assessment 7: 1347-1362.

Rolton A, Vignier J, Volety A, Shumway S, Bricelj VM, Soudant P (2018) Impacts of exposure to the toxic dinoflagellate Karenia brevis on reproduction of the northern quahog, Mercenaria mercenaria. Aquatic Toxicology 202: 153-162.

Rosetta CH, McManus GB (2003) Feeding by ciliates on two harmful algal bloom species, Prymnesium parvum and Prorocentrum minimum. Harmful Algae 2: 109-126.

Roth PB, Mikulski CM, Doucette GJ (2008) Influence of microbial interactions on the susceptibility of Karenia species to algicidal bacteria. Aquatic Microbial Ecology 50: 251-259.

Ruiz-Villarreal M, García-García LM, Cobas M, Díaz PA, Reguera B (2016) Modelling the hydrodynamic conditions associated with Dinophysis blooms in Galicia (NW Spain). Harmful Algae 53: 40-52.

S-3 EuroHAB (2019) Project S-3 EUROHAB to Monitor Harmful Algal Blooms From Space. EU Interreg Programme. URL (accessed 26 August 2019): https://interreg5a-fce.eu/en/newsand-events/news/project-s-3-eurohab-to-monitor-harmfulalgal-blooms-from-space/

Schmidt W, Evers-King HL, Campos CJA, Jones DB, Miller PI, Davidson K et al. (2018) A generic approach for the development of short-term predictions of $E$. coli and biotoxins in shellfish; application to a coastal bay and an estuary. Aquaculture and Environment Interactions 10: 173-185.

Seger A, Dorantes-Aranda J, Müller M, Body A, Peristyy A, Place A et al. (2015) Mitigating fish-killing Prymnesium parvum algal blooms in aquaculture ponds with clay: the importance of $\mathrm{pH}$ and clay type. Journal of Marine Science and Engineering 3: 154-174.

Seger A, Park T-G, Hallegraeff G (2017) Assessment of the efficacy of clay flocculation in Korean fish farm waters: Cochlodinium cell removal and mitigation of ichthyotoxicity. Harmful Algae 61: 46-55.

Selander E, Fagerberg T, Wohlrab S, Pavia H (2012) Fight and flight in Dinoflagellates? Kinetics of simultaneous grazer-induced responses in Alexandrium tamarense. Limonology and Oceanography 57: 58-64.

Sellner KG, Rensel JE (2018) Prevention, control and mitigation of Harmful Algal Bloom impacts on fish shellfish and human consumers. In: Shumway SE, Burkholder JM, Morton SL (eds), Harmful Algal Blooms a Compendium Desk Reference, pp. 435-492. John Wiley \& Sons Inc., Hoboken, NJ. 
Sellner KG, Doucette GJ, Kirkpatrick GJ (2003) Harmful algal blooms: causes, impacts and detection. Journal of Industrial Microbiology and Biotechnology 30: 383-409.

Sephton DH, Haya K, Martin JL, LeGresley MM (2007) Paralytic shellfish toxins in zooplankton, mussels, lobsters and caged Atlantic salmon, Salmo salar, during a bloom of Alexandrium fundyense off Grand Manan Island, in the Bay of Fundy. Harmful Algae 6: 745-758.

Shi J, Wei H (2009) Simulation of hydrodynamic structures in a semi-enclosed bay with dense raft-culture. Periodical of Ocean University of China 39: 1181-1187.

Shi F, McNabb P, Rhodes L, Holland P, Webb S, Adamson J et al. (2012) The toxic effects of three dinoflagellate species from the genus Karenia on invertebrate larvae and finfish. New Zealand Journal of Marine and Freshwater Research 46 (2): 149-165.

Shirota A (1989) Red tide problem and countermeasures. International Journal of Fisheries and Aquaculture 1: 195-223.

Shumway SE (1995) Phycotoxin-related shellfish poisoning: bivalve molluscs are not the only vectors. Reviews of Fishery Science 3: 1-31.

Shumway SE, Barter J, Sherman-Caswell S (1990) Auditing the impact of toxic algal blooms on oysters. Environmental Auditor 2: 41-56.

Shumway SE, Burkholder JM, Morton SL (2018) Harmful Algal Blooms A Compendium Desk Reference. John Wiley \& Sons Inc., Hoboken, NJ.

Shutler JD, Warren MA, Miller PI, Barciela R, Mahdon R, Land $\mathrm{PE}$ et al. (2015) Operational monitoring and forecasting of bathing water quality through exploiting satellite Earth observation and models: the AlgaRisk demonstration service. Computers \& Geosciences 77: 87-96.

Silke J, O’Beirn F, Cronin M (2005) Karenia mikimotoi: An Exceptional Dinoflagellate Bloom in Western Irish Waters, Summer 2005, Marine Environment and Health Series No. 21, 48 page. Marine Institute. (accessed November 2019). Available from URL: https://oar.marine.ie/bitstream/handle/10793/240/ No\%2021\%20Marine\%20Environment\%20and\%20Health\% 20Series.pdf;jsessionxml:id=DD29022691DFCCBB7EAEFBD A7FC29D54? sequence $=1$

Smayda TJ (1989) Causes and impacts of recurrent brown tide and other unusual blooms. In: Cosper EM, Carpenter EJ, Bricelj M (eds) Novel Phytoplankton Blooms, pp. 213-228. Springer-Verlag, New York, NY.

Smayda TJ (1997) Harmful algal blooms: their ecophysiology and general relevance to phytoplankton blooms in the sea. Limnology and Oceanography 42: 1137-1153.

Smayda TJ (2004) Harmful algal bloom communities in Scottish coastal waters: relationship to fish farming and regional comparisons - a review. Scottish Executive Environment Group Paper 2006/3.

Smayda TJ, Reynolds CS (2001) Community assembly in marine phytoplankton: application of recent models to harmful dinoflagellate blooms. Journal of Plankton Research 23(5): 447-461.
Smayda TJ, Trainer VL (2010) Dinoflagellate blooms in upwelling systems: seeding, variability, and contrasts with diatom bloom behaviour. Progress in Oceanography 85(1-2): 92107.

Soliño L, Ferrer-Obiol J, Navarro-Herrero L, González-Solís J, Reis Costa PR (2019) Are pelagic seabirds exposed to amnesic shellfish poisoning toxins? Harmful Algae 84: 172-180.

Soto D (2009) Integrated Mariculture: A Global Review. FAO Fisheries and Aquaculture Technical Paper No. 529. FAO, Rome, Italy. 183pp. URL (accessed 29 December 2018): www.fao.org/docrep/012/i1092e/i1092e00.htm.

Soto D, Aguilar-Manjárrez J (2009) FAO Expert Workshop on "Guidelines for the Implementation of an Ecosystem Approach to Aquaculture (EAA)”. FAO Aquaculture Newsletter 42, pp. 8-9. FAO, Rome, Italy.

Sourisseau M, Jegou K, Lunven M, Quere J, Gohin F, Bryere P (2016) Distribution and dynamics of two species of Dinophyceae producing high biomass blooms over the French Atlantic Shelf. Harmful Algae 53: 53-63.

Stadmark J, Conley DJ (2011) Mussel farming as a nutrient reduction measure in the Baltic Sea: consideration of nutrient biogeochemical cycles. Marine Pollution Bulletin 62: 13851388.

Staley ZR, Harwood VJ, Rohr JR (2015) A synthesis of the effects of pesticides on microbial persistence in aquatic ecosystems. Critical Reviews in Toxicology 45: 813-836.

Stüken A, Orr RJS, Kellmann R, Murray SA, Neilan BA, Kjetill SJ (2011) Discovery of nuclear-encoded genes for the neurotoxin saxitoxin in dinoflagellates. PLoS ONE 6: e0020096.

Sun R, Sun P, Zhang J, Esquivel-Elizondo S, Wu Y (2018) Microorganisms-based methods for harmful algal blooms control. Annual Reviews in Bioresource Technology 248(Pt. B): 12-20.

Svendsen MBS, Andersen NR, Hansen PJ, Steffensen JF (2018) Effects of Harmful Algal Blooms on fish: Insights from Prymnesium parvum. Fishes 3: 11.

Tang YZ, Gobler CJ (2011) The green macroalga, Ulva lactuca, inhibits the growth of seven common harmful algal bloom species via allelopathy. Harmful Algae 10: 480-488.

Toth GB, Norén F, Selander E, Pavia H (2004) Marine dinoflagellates show induced life-history shifts to escape parasite infection in response to water-borne signals. Proceedings of the Royal Society: B 271: 733-738.

Touzet N, Davidson K, Romain P, McCoy GR, Amzil Z, Maher $\mathrm{M}$ et al. (2010) Co-occurrence of the West European (Gr. III) and North American (Gr. I) ribotypes of Alexandrium tamarense (Dinophyceae) in Shetland, Scotland. Protist 161: 370384.

Trainer VL, Yoshida T (2014) Proceedings of the Workshop on Economic Impacts of Harmful Algal Blooms on Fisheries and Aquaculture. PICES Scientific Reports 47: 85.

Trainer VL, Bates SS, Lundholm N, Thessen AE, Cochlan WP, Adams NG et al. (2012) Pseudo-nitzschia physiological ecology, phylogeny, toxicity, monitoring and impacts on ecosystem health. Harmful Algae 14: 271-300. 
Troell M, Joyce A, Chopin T, Neori A, Buschmann AH, Fang JG (2009) Ecological engineering in aquaculture - potential for integrated multi-trophic aquaculture (IMTA) in marine offshore systems. Aquaculture 297: 1-9.

Turner JT, Tester PA (1997) Toxic marine phytoplankton, zooplankton grazers, and pelagic food webs. Limnology and Oceanography 42: 1203-1214.

Turner AD, Higgins C, Davidson K, Veszelovszki A, Payne D, Hungerford J et al. (2015) Potential threats posed by new or emerging marine biotoxins in UK Waters and examination of detection methodology used in their control: Brevetoxins. Marine Drugs 13: 1224-1254.

Twiner MJ, Rehmann N, Hess P, Doucette GJ (2008) Azaspiracid Shellfish Poisoning: a review on the chemistry, ecology, and toxicology with an emphasis on human health impacts. Marine Drugs 6(2): 39-72.

UN (2017) The 2017 Revision of World Population Prospects. URL (accessed 31 December 2018): https://population.un. org/wpp/

Uyaguari M, Scott G, Norman RS (2013) Abundance of class 1-3 integrons in South Carolina estuarine ecosystems under high and low levels of anthropogenic influence. Marine Pollution Bulletin 15: 77-84.

Wang Y, Yu Z, Song X, Tang X, Zhang S (2007) Effects of macroalgae Ulva pertusa (Chlorophyta) and Gracilaria lemaneiformis (Rhodophyta) on growth of four species of bloomforming dinoflagellates. Aquatic Botany 86: 139-147.

Wang S, Tang D, He F, Fukuyo Y, Azanza RV (2008) Occurrences of Harmful Algal Blooms (HABs) associated with ocean environments in the South China Sea. Hydrobiologia 596: 79-93.

Ward JE, Shumway SE (2004) Separating the grain from the chaff: particle selection in suspension- and deposit-feeding bivalves. Journal of Experimental Marine Biology and Ecology 300: 83-130.

Wartenberg R, Feng L, Jun WuJ, Mak YL, Chan LL, Telfer TC et al. (2017) The impacts of suspended mariculture on coastal zones in China and the scope for Integrated MultiTrophic Aquaculture. Ecosystem Health and Sustainability 3: 1340268 .

Watkins SM, Reich A, Fleming LE, Hammond R (2008) Neurotoxic Shellfish Poisoning. Marine Drugs 6: 431-455.

Watts JEM, Schreier HJ, Lanska L, Hale MS (2017) The rising tide of antimicrobial resistance in aquaculture: sources, sinks and solutions. Marine Drugs 15: 158.

Wells ML, Trick CG, Cochlan WP, Hughes P, Trainer VL (2005) Domoic Acid: the synergy of iron, copper and the toxicity of diatoms Limnol. Oceanography 50: 1908-1917.

Wells ML, Trainer VL, Smayda TJ, Karlson BS, Trick CG, Kudela RM et al. (2015) Harmful algal blooms and climate change: learning from the past and present to forecast the future. Harmful Algae 49: 68-93.
Wells ML, Karlson B, Wulff A, Kudela R, Trick C, Asnaghi V et al. (2019). Future HAB science: Directions and challenges in a changing climate. Harmful Algae, available online, doi.org/10.1016/j.hal.2019.101632.

WHO (2003) Algae and cyanobacteria in coastal and estuarine waters in Guidelines for Safe Recreational Water Environments, pp. 128-136. URL (accessed 16 April 2017): http:// apps.who.int/iris/bitstream/10665/42591/1/9241545801.pdf

Whyte C, Swan S, Davidson K (2014) Changing wind patterns linked to unusually high Dinophysis blooms around the Shetland Islands, Scotland. Harmful Algae 39: 365-373.

Wiese M, D’Agostino PM, Mihali TK, Moffitt MC, Neilan BA (2010) Neurotoxic Alkaloids: Saxitoxin and its analogs. Marine Drugs 8: 2185-2211.

Wilson WH, Tarran GA, Schroeder D, Cox M, Oke J, Malin G (2002) Isolation of viruses responsible for the demise of an Emiliania huxleyi bloom in the English Channel. Journal of the Marine Biological Association UK 82: 369-377.

Wolrhab S (2013) Characterization of grazer-induced responses in the marine dinoflagellate Alexandrium tamarense. $\mathrm{PhD}$ Dissertation, Universität Bremen, Germany.

Woolhouse MEJ, Ward MJ (2013) Sources of Antimicrobial Resistance. Science 341: 1460-1461.

Yahel G, Marie D, Beninger PG, Eckstein S, Genin A (2009) In situ evidence for pre-capture qualitative selection in the tropical bivalve Lithophaga simplex. Aquatic Biology 6: 235-246.

Yang Y, Chai Z, Wang Q, Chen W, He Z, Jiang S (2015) Cultivation of seaweed Gracilaria in Chinese coastal waters and its contribution to environmental improvements. Algal Research 9: 236-244.

Yu Z, Song X, Cao X, Liu Y (2017) Mitigation of harmful algal blooms using modified clays: theory, mechanisms, and applications. Harmful Algae 69: 48-64.

Zeng D, Huang D, Qiao X, He Y, Zhang T (2015) Effect of suspended kelp culture on water exchange as estimated by in situ current measurement in Sanggou Bay, China”. Journal of Marine Systems 149: 14-24.

Zerrifi SEA, El Khalloufi F, Oudra B, Vasconcelos V (2018) Seaweed bioactive compounds against pathogens and microalgae: potential uses on pharmacology and Harmful Algae Bloom control. Marine Drugs 16 (2): E55.

Zhang C, Zhang J (2015) Current techniques for detecting and monitoring algal toxins and causative harmful algal blooms. Journal of Environmental Analytical Chemistry 2: 123.

Zhang QC, Qiu LM, Yu RC, Kong FZ, Wang YF, Yan T et al. (2012) Emergence of brown tides caused by Aureococcus anophagefferens Hargraves et Sieburth in China. Harmful Algae 19: 117-124.

Zhou Y, Yang H, Hu H, Liu Y, Mao Y, Zhou H et al. (2006) Bioremediation potential of the macroalga Gracilaria lemaneiformis (Rhodophyta) integrated into fed fish culture in coastal waters of North China”. Aquaculture 252: 264-276. 